\title{
Engineering Characteristics and Potential Increased Utilisation of Sawdust Composites in Construction-A Review
}

\author{
Abraham Mwango, Chewe Kambole* \\ Department of Civil Engineering and Construction, Copperbelt University, Kitwe, Zambia \\ Email: *ckambole.snr@gmail.com, ${ }^{*}$ chewe.kambole@cbu.ac.zm
}

How to cite this paper: Mwango, A. and Kambole, C. (2019) Engineering Characteristics and Potential Increased Utilisation of Sawdust Composites in Construction-A Review. Journal of Building Construction and Planning Research, 7, 59-88. https://doi.org/10.4236/jbcpr.2019.73005

\section{Received: July 11, 2019}

Accepted: September 15, 2019

Published: September 18, 2019

Copyright (c) 2019 by author(s) and Scientific Research Publishing Inc. This work is licensed under the Creative Commons Attribution International License (CC BY 4.0).

http://creativecommons.org/licenses/by/4.0/

\begin{abstract}
Many timber producing countries generate more than 2 million $\mathrm{m}^{3}$ of sawdust annually. In developing countries, sawdust is often disposed of by open dumping, open burning, or dumping in landfills. This poses huge environmental challenges related to air pollution, greenhouse gas emissions, and destruction of plant and aquatic life. Findings from this review article reveal that sawdust can be used to make sawdust construction composites with good modulus of elasticity, water absorption and strength characteristics that satisfy international specifications. These composites include particleboards, sawdust concrete blocks or bricks and sawdust concrete. The article concludes that partially replacing $5 \%$ to $17 \%$ of sand with sawdust, or replacing cement with sawdust ash in proportions of $5 \%$ to $15 \%$ in concrete mixes can produce structural concrete with compressive strengths greater than $20 \mathrm{MPa}$. Partially replacing $10 \%$ to $30 \%$ of sand used in the manufacture blocks and bricks with sawdust can also produce sawdust bricks and blocks with compressive strengths greater than $3 \mathrm{MPa}$. Sawdust composites are also attractive for their low thermal conductivity, high sound absorption and good sound insulation characteristics. These findings indicate that increased utilisation of sawdust composites in construction will mitigate against potential sawdust environmental pollution, conserve energy and reduce disposal costs.
\end{abstract}

\section{Keywords}

Sawdust, Sawdust Composites, Compressive Strength, Thermal Conductivity, Sound Absorption

\section{Introduction}

Sawdust is a waste or by-product from a range of timber manufacturing processes 
that include sawing, planning, routing, drilling, sanding operations, furniture manufacturing and joinery. This waste stream comprises small discontinuous chips or simply fine particles of wood [1] [2].

The disposal of sawdust is often by open dumping, open burning, or dumping in landfills [3] [4]. Sawdust dumped in landfills increases the burden on landfill sites and burning it contributes to greenhouse gas emissions [5]. Despite the air pollution and public health challenges associated with open burning, it is commonly practiced by saw millers as the easiest way to get rid of sawdust [6] [7]. When dumped on stream and river banks sawdust is transported by rainwater or wind into the surface water and can severely affect aquatic life. Moreover, sawdust indiscriminately dumped on land kills plant life and causes wood dust when blown into the atmosphere [8].

Creating value from this waste stream would reduce disposal costs and create jobs [5]. Additionally, utilising wood-based products such as sawdust composites in construction contributes to climate change mitigation [9] [10]. Substituting steel, concrete, and other high energy manufactured products with sawdust composites has the potential to reduce the consumption of large amounts of fossil fuels. Considering that wood based products store carbon for the duration of their life cycle, the use of sawdust composites, accordingly, leads to reduced $\mathrm{CO}_{2}$ emissions [10] [11] and therefore mitigates against global warming.

The motivation for this review article is that sawdust, an environmental hazard, has great potential for use as a raw material to produce construction composites that meet international standards. This potential use is yet to be fully explored, particularly in developing countries where indiscriminate dumping of sawdust is rife. The article briefly highlights some environmental challenges that sawdust poses and reviews engineering characteristics of sawdust construction composites, namely, particleboards, sawdust concrete blocks, bricks and lightweight sawdust concrete. It is envisaged that the reviewed literature will serve as a catalyst for more research on sawdust composites and for promoting increased utilisation of these composites in construction. This would further contribute to the development of green building materials and mitigate against the sawdust environmental pollution threat. The data presented and discussed in this article is also beneficial to researchers studying alternative construction materials aimed at conserving non-renewable natural resources and energy.

\section{Production, Non-Construction Common Usage and Disposal of Sawdust}

\section{1) Amount of sawdust produced from sawmills}

The sawmilling operation is one of the major sources of sawdust. The amount of sawdust produced from sawmilling depends on the sawmill efficiency which can be measured by the quality and quantity of sawn plank recovered compared with the resulting wood waste. This wood waste is a combination of bark, sawdust, trimming, split wood, planer shavings and sander dust [12]. The type of 
machinery used also has a bearing on the quantity of sawdust generated. Kambugu et al. [13] observed that lack of proper machinery for the timber sawing leads to high generation of saw dust in the timber sawing process.

Table 1 shows the amount of wood waste and sawdust generated from sawmills as well as some annual sawdust production quantities in selected regions around the world. It is noted from Table 1 that in many timber producing countries, more that 2 million $\mathrm{m}^{3}$ of saw dust is generated annually from sawmilling operations. In Zambia's Copperbelt province, like in many developing countries, large piles of sawdust, slabs, off cuts and bark are characteristic of operation areas of the province's 13 registered saw millers. This indicates a huge environmental challenge if this material is simply left as waste.

\section{2) Common non-construction usage and disposal of sawdust}

Common non-construction usage of the sawdust include bedding for poultry and livestock, soil composting and mulching [21]. Before the advent of refrigeration, it was used to keep ice frozen in icehouses during summer. When mixed with water and then frozen, it forms a slow-melting and stronger form of ice. Sometimes it is used to soak up spilled liquids, thus enabling the easy collection or sweeping away of the spill [1]. Sawdust is also considered a very good raw material for the production of wood pellets and biomass briquettes used as solid fuels [20] [22] [23].

Table 1. Approximate quantities of sawdust generated annually from sawmills.

\begin{tabular}{|c|c|c|c|c|}
\hline $\begin{array}{c}\text { Proportion of wood } \\
\text { waste generated from } \\
\text { total sawmilling input } \\
\text { volume (\%) }\end{array}$ & $\begin{array}{l}\text { Proportion of } \\
\text { sawdust } \\
\text { produced (\%) }\end{array}$ & $\begin{array}{l}\text { Amount of } \\
\text { sawdust produced } \\
\text { per annum } \\
\left(\text { million } \mathrm{m}^{3}\right)\end{array}$ & Country & Reference \\
\hline $31-56$ & $16-35^{\star}$ & $8.6^{\dagger}$ & Nigeria & $\begin{array}{c}\text { Ekhuemelo and Atondo } \\
{[12][14]}\end{array}$ \\
\hline 44 & 10 & & Nigeria & Olufemi et al. [15] \\
\hline 60 & $10-25$ & $0.031^{* *}$ & Zambia & Ncube and Phiri [16] \\
\hline 48 & 20 & $4.7^{\dagger}$ & South Africa & $\begin{array}{l}\text { Department of } \\
\text { Environmental Affairs } \\
\text { (DEA) [17] }\end{array}$ \\
\hline 27.5 & 14.7 & - & Ghana & Adu et al. [4] \\
\hline- & 35 & $9.5^{\dagger}$ & Mexico & Guzman and Munno [18]. \\
\hline- & - & 2.72 & Chile & Garay [19] \\
\hline- & - & 2.8 & Austria & \multirow{4}{*}{$\begin{array}{l}\text { European Organisation } \\
\text { of the Sawmill Industry } \\
\text { (EOS) }[20]^{\dagger \dagger}\end{array}$} \\
\hline- & - & 4.8 & Germany & \\
\hline- & - & $\begin{array}{l}3.4 \\
0.54\end{array}$ & $\begin{array}{l}\text { Finland } \\
\text { Latvia }\end{array}$ & \\
\hline- & - & 5.3 & Sweden & \\
\hline
\end{tabular}

${ }^{*}$ Data based 9 out of 10 studied sawmills; ${ }^{* *}$ Data from sawmills in 1 out 10 provinces of Zambia; - No data available; ${ }^{\dagger}$ Amount evaluated from volumes using an approximate sawdust density of $210 \mathrm{~kg} / \mathrm{m}^{3}$; ${ }^{\dagger \dagger}$ Average values from four years sawdust generation figures. 
Common disposal of most of this waste include open dumping, open burning and sometimes dumping in landfills. Figure 1 shows indiscriminate dumping and burning of sawdust, typical in developing countries.

\section{Current Use of Sawdust Composites in Construction}

Sawdust composites have been applied in construction for a long time. For example it has been used to produce sawdust concrete for more than 40 years [1]. Apart from its use in concrete, literature indicates that other sawdust composites used in the construction industry include particleboards, floor panels, partitioning, cladding, ceiling, formwork and concrete blocks and bricks.

\subsection{Particleboards and Related Products}

A considerable amount of sawdust and wood shavings in the United States of America is utilised in the manufacturing of particleboards [24]. The global production of wood based panels that include particleboards, plywood, oriented strand boards (OSBs) and fiberboards increased by 125\% between 2000 and 2017 [25]. Between 2012 and 2016 the largest proportion (62\%) of these products were manufactured in the Asia-Pacific region, followed by Europe (21\%), North America (11\%), Latin America and the Caribbean (5\%) and Africa (1\%) [26]. The low manufacturing figure for Africa and other developing continents compared with the high sawdust produced (Table 1) implies that there is great potential

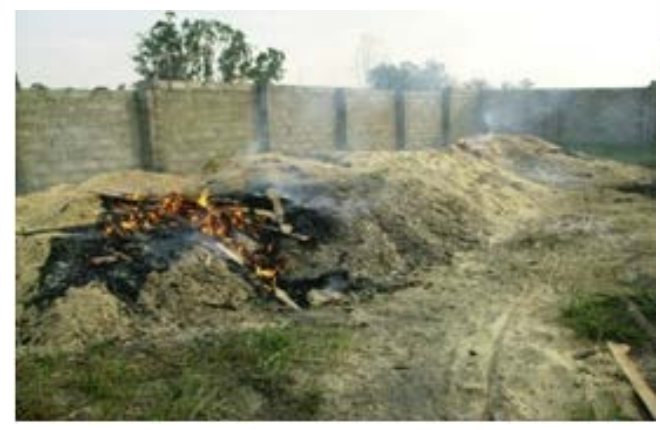

(a)

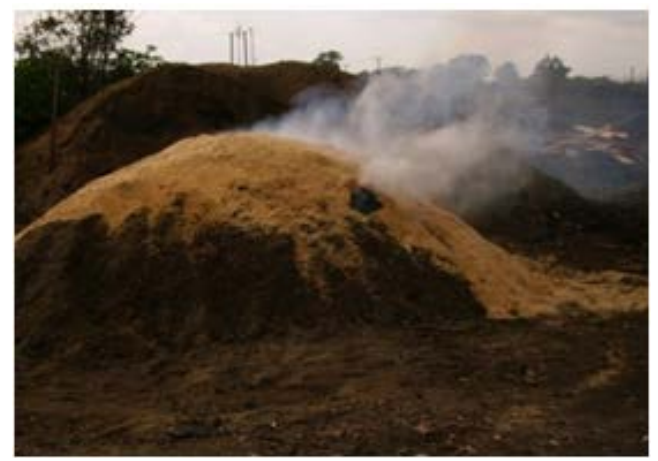

(c)

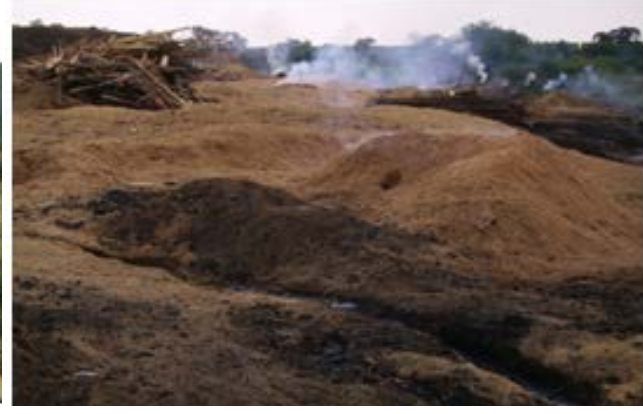

(b)

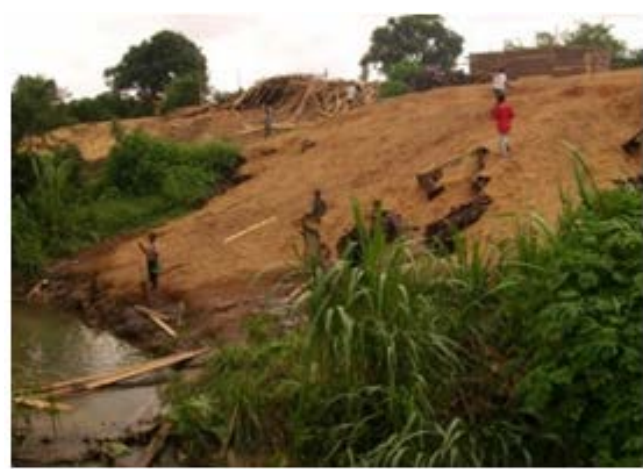

(d)

Figure 1. Open dumping of sawdust: (a) Burning of sawdust near residential area; (b) and (c) Burning of sawdust at a sawmill; (d) Dumping of sawdust on the banks of a stream. 
for increased manufacture of sawdust construction composites from this waste in developing countries.

In Zambia, the demand for particleboards and related products like plywood and sawn timber is continuously rising. A $39 \%$ increase in demand for these products, from $501,100 \mathrm{~m}^{3}$ in 2010 to $698,700 \mathrm{~m}^{3}$ in 2025 , has been projected [27]. It is envisaged that incorporation of sawdust in the manufacturing of these particleboards will mitigate against the environmental pollution that this waste poses in Zambia.

Particleboards and related wood products such as low-density fibreboard (LDF), and chipboard are manufactured by mixing various proportions of wood chips, sawmill shavings, or sawdust with a synthetic resin or any suitable binder [9] [28]. For example, Abdulkareem et al. [28] established that particleboards made from sawdust and plastic based resin (PBR) synthesised from waste styrofoam as binder exhibited properties that were in tandem with the requirements of the American National Standard Institute (ANSI) A208.1 requirements. This standard specifies the required dimensions as well as the physical and mechanical properties for different grades of particleboards. The study observed that the sawdust-PBR particleboards exhibited better water penetration resistance, dimensional stability, mechanical properties and resistance to deformation when compared with urea formaldehyde (UF) particleboards. They were thus more durable, tougher, and better suited for application in most environments than the UF particleboards.

A study by Dotun, A.O. et al. [29] observed that sawdust particleboards produced from a combination of sawdust and polyethylene terephthalate plastic waste was favourable for indoor applications. However, the study also showed that these products had limited structural and load bearing applications. Similarly Akinyemi et al. [30] recommended that panels produced as corncob and sawdust composites using urea formaldehyde as binder were suitable for indoor uses in buildings but not for load bearing purposes.

Erakhrumen et al. [31] proved that for mixtures of pine (Pinus caribaea M.) sawdust and coconut husk or coir (Cocos nucifera L.) using cement as binder, parameters such as water resistance, strength properties and density of the particleboards were enhanced with high cement content. However, these properties were lowered with increased inclusion of coir in the mixture.

Sawdust composites made from gluing of sawdust or wood chips together with expanded polystyrene are known to exhibit good thermal conductivity characteristics. These products are deemed appropriate for use in room partitioning and suspended ceilings [32].

\subsection{Floor Panels}

A study by Chanhoun et al. [33] investigated a combination of wood waste, polystyrene waste and plastic waste composites. The study indicated that these composites could be used, not only for interior and exterior flooring but also as self-adhesive sandwich panels or boards in door cores, false ceilings and form- 
work sandwich boards.

An innovative concrete sandwich panel investigated in Iraq was made using a layer of light weight concrete (LWC), sandwiched between two outer layers of reinforced concrete. These elements were connected together by truss reinforcement as shear connectors. The strength of the sandwich slab panel with sawdust, which was used as aggregate in the inner wythe, was greater than the strength of sandwich slab panel with polystyrene (styropor) or porcilenite [34].

Chung et al. [35] demonstrated the vibration damping potential of a sand-sawdust layer in lightweight timber-framed floor/ceiling systems (LTFSs). The studied LTFS comprised an upper floor made of a sand-sawdust mixture, a cavity space filled with fibre infill for sound damping and a ceiling. The theoretical model and the experimental measurements showed that the sand-sawdust layer dampened the vibration in the frequency range of between 10 and $200 \mathrm{~Hz}$.

\subsection{Partitioning and Cladding}

Sawdust-cement composites could be utilised for cladding and walling. An important consideration for this application, however, is the need to carefully select wood with suitable constituents for cement compatibility [36].

\subsection{Sawdust Concrete Blocks or Bricks and Mortar}

Various studies have been done in the quest to come up with green and less costly construction blocks that incorporate sawdust in raw form or in the form of sawdust ash. Mangi et al. [37] provides a good overview of 17 studies carried out on concrete masonry blocks between 2012 and 2016 in 11 different countries. This review underscores the potential for increased utilisation of sawdust concrete blocks as lightweight masonry units in buildings.

Gil et al. [38] observed that wood sawdust waste has a positive effect on the post-cracking of building mortar. This in turn improves the ductility of mortar. Claudiu [8] studied the use of sawdust in plaster mortars. The study highlighted important characteristics of the investigated plaster mortars that included their good sound and thermal insulation capacity and non-susceptibility to ignition from open flame. These mortars were thus recommended for application in interior walls of buildings.

\subsection{Lightweight Sawdust Concrete}

Lightweight concrete is concrete with densities of between 300 and $1850 \mathrm{~kg} / \mathrm{m}^{3}$. Structural lightweight concrete has densities of between 1120 and $1920 \mathrm{~kg} / \mathrm{m}^{3}$ and has a minimum compressive strength of $17 \mathrm{MPa}$ [39] [40]. The low density and high thermal insulation value of waste wood aggregate such as sawdust [24] makes it a good alternative ingredient for the production of lightweight concrete and thermal insulation construction composites. Ahmed et al. [41] observed that a mix design of coarse aggregate, sand and cement, with different dosages of sawdust as partial replacement for sand, produced eco-friendly and thermal efficient normal and lightweight concretes. 


\section{Engineering Characteristics and Performance of Sawdust Composites Used in Construction}

\subsection{Particleboards}

Badejo [42] observed that $12 \mathrm{~mm}$ thick cement-bonded particleboards made of sawdust from four tropical hardwood species (Mitragyna ciliata, Triplochiton scleroxylon, Terminalia superba and Ceiba pentandra) had strong effect on the board properties tested. The evaluated modulus of rapture (MOR) ranged from 4.72 to $8.20 \mathrm{MPa}, 5.00$ to $8.00 \mathrm{MPa}, 4.35$ to $6.05 \mathrm{MPa}$ and 3.75 to $6.20 \mathrm{MPa}$ respectively for the four wood species. The modulus of Elasticity (MOE) ranged from 2750 to $4000 \mathrm{MPa}, 2500$ to $3500 \mathrm{MPa}, 2500$ to $3400 \mathrm{MPa}$ and 2100 to 3350 $\mathrm{MPa}$ respectively for the four wood species. After soaking in cold water for 72 hours, the percentage thickness swelling ranged from $2.80 \%$ to $4.5 \%, 2.9 \%$ to $5.5 \%, 2.2 \%$ to $3.55 \%$ and $4.50 \%$ to $5.70 \%$ for the four woods. The respective approximate densities of these wood species are between 450 and 560, 320 and 400, 450 and 580 and 230 and $260 \mathrm{~kg} / \mathrm{m}^{3}$ [43] [44]. The MOE properties, of the experimental boards relate with the densities of the woods used. The Mitragyna ciliata and Terminalia superba species have higher densities and yielded higher MOE values than the other two species. It is also noted that the MOE results from this study satisfy the ANSI 208.1 specifications [45] for high and medium grade particleboards. However, the MOR results did not meet the ANSI 208.1 requirements. The studied particleboards exhibited acceptable swelling behaviour, considering that BS EN 312:2010 [46] and BS EN 317:1993 [47] stipulate that particleboards should have a maximum thickness swelling (TS) value of $8 \%$ if subjected to 2 hours water immersion, or a maximum TS of $15 \%$ if the 24 hours water immersion procedure is used.

Okhuen wood sawdust and recycled polyethylene (RLDPE) were blended and then hot-pressed to produce sawdust/recycled polyethylene composite board by Atuanya and Obele [48]. The investigated average tensile strength of the optimised composite board was $13.991 \mathrm{MPa}$, a value that met the specifications for general applications.

Abu-Zarifa et al. [49] examined particleboards that were manufactured from sawdust and agricultural waste (banana stems, wheat bran and orange peels). Each agricultural waste was mixed with sawdust in two proportions of $25 \%$ and $75 \%$ while the amount of polypropylene plastic was kept constant at $40 \%$. The mixes were pressed under a 24 ton load, at a temperature of $170^{\circ} \mathrm{C}$ for 2.5 hours. The test results showed a maximum modulus of elasticity (MOE) value of $2160.78 \mathrm{MPa}$ for the mix with $75 \%$ wheat composition, a maximum modulus of rapture (MOR) value of $11.07 \mathrm{MPa}$ for the mix with $100 \%$ sawdust composition, and a maximum-stress value of $7.8 \mathrm{MPa}$ for the mix with $25 \%$ banana composition. The range of water absorption values were between $8.19 \%$ and $19.3 \%$. These results were better than the commercial type particleboards (Medium Dense Fiber, Fiber and Press wood boards). The particleboard mix with $75 \%$ banana composition exhibited the least water absorption and swelling capacity. The 
one with $75 \%$ orange composition showed the highest water absorption and swelling percent.

\subsection{Sawdust in Concrete Blocks or Bricks and Mortar}

Kupolati et al. [50] investigated the utilization of sawdust as partial replacement of crusher sand for the production of bricks as a way of enhancing the greening of the environment. Sawdust was used as a partial replacement for crusher sand at $1 \%, 3 \%$ and $5 \%$ by volume. The investigated compressive strength values of the sawdust-sand bricks produced on site was less than the minimum values of 4.0 MPa specified for solid masonry units in masonry walls [51]. The average compressive strength of the bricks $(290 \mathrm{~mm} \times 150 \mathrm{~mm} 90 \mathrm{~mm})$ on site at 28 days was $0.67 \mathrm{MPa}, 0.23 \mathrm{MPa}$ and $0.21 \mathrm{MPa}$ for the respective sawdust replacement percentages. However, the bricks cubes measuring $100 \mathrm{~mm} \times 100 \mathrm{~mm} \times 100 \mathrm{~mm}$ produced in the laboratory yielded average compressive strengths of $6.10 \mathrm{MPa}$, 5.73 $\mathrm{MPa}$ and 3.7 $\mathrm{MPa}$ for the aforementioned respective sawdust replacement percentages. This was attributed to better quality control practices in the laboratory. This study stressed the importance of quality control in the bulk production of sawdust bricks. The research further showed the potential use of sawdust as a partial replacement material for crusher sand in the production of bricks.

To investigate the potential use of sawdust in blocks, Ravindrarajah et al. [52] evaluated blocks made using cement, lime, fly ash, calcium chloride, Radiata Pine sawdust, sand and water. A sawdust concrete block mix with $12 \%$ sawdust content by volume produced a density of $1540 \mathrm{~kg} / \mathrm{m}^{3}$ and a 28-day compressive strength of $14 \mathrm{MPa}$. The use of $2 \%$ calcium chloride led to the achievement of optimum strength at all ages but also caused significant increase in shrinkage. The study observed that sawdust is a good filler material for the production of lightweight concrete blocks.

Replacing sand with sawdust in a sand-cement block mix, sawdust replacement proportions of $10 \%, 20 \%, 30 \%$, and $40 \%$, with water cement ratio of 0.5 was investigated by Dadzie et al. [53]. Compressive strengths of the investigated sawdust composite blocks exceeded the minimum BS 6073 requirement of 2.8 $\mathrm{MPa}$ for sawdust replacement of not more $10 \%$.It was further noted that the sawdust replacement content should not exceed $10 \%$ if sawdust blocks were to meet standard specifications.

Boob [54] established that sandcrete blocks prepared by partially replacing sand with sawdust gave optimum and desired results from a 1:6 (cement: sand + sawdust) ( $85 \%$ sand $+15 \%$ sawdust $)$ mix ratio. The compressive strength obtained from $100 \mathrm{~mm} \times 100 \mathrm{~mm} \times 100 \mathrm{~mm}$ blocks for this mix proportion was 4.5 MPa. This is a good result for blocks made with sawdust replacement of not more than $10 \%$, when evaluated in relation to the minimum BS 6073 requirement of 2.8 MPa [55].

Ettu et al. [56] investigated the use of ordinary Portland cement (OPC), saw- 
dust ash (SDA) and pawpaw leaf ash (PPLA) for possible production of sandcrete blocks, (where sand was the major constituent), and soilcrete blocks, with laterite being the major constituent. Binary cementing blends of OPC-SDA and OPC-PPLA and ternary cementing blends of OPC-SDA-PPLA for the production of the blocks were evaluated. The study observed that the produced blocks from these blended cementing materials yielded sufficient strength for their use particularly in civil engineering works where the need for high early strength was not a critical factor. The 150-day strength values for OPC-SDA-PPLA ternary blended cement, for sandcrete and soilcrete blocks were, respectively, 6.00 $\mathrm{MPa}$ and 5.20 MPa for 5\% replacement, 5.90 MPa and 5.10 MPa for $10 \%$ replacement, $5.75 \mathrm{MPa}$ and $5.00 \mathrm{MPa}$ for $15 \%$ replacement of OPC, and $5.70 \mathrm{MPa}$ and $4.90 \mathrm{MPa}$ for $20 \%$ replacement of OPC. These results were slightly better than the respective control values of 5.20 $\mathrm{MPa}$ and 4.80 MPa.

Investigations by Turgut and Algin [57] used limestone powder wastes (LPW) from quarrying operations and wood sawdust wastes (WSW) produced from the sawing process of raw wood to obtain WSW-LPW bricks. These composite bricks with varying WSW-LPW combinations yielded compressive strength, flexural strength, unit weight, ultrasonic pulse velocity (UPV) and water absorption values that satisfied international standards, namely ASTM C67-03a, BS 6073 and BS 1881. A 30\% replacement of WSW in the brick composite mix produced bricks with a compressive strength of $7.2 \mathrm{MPa}$ and a flexural strength of 3.1 MPa. These results comply with the BS6073 requirements for building materials to be used in structural applications. This sawdust composite was evaluated as a potential wall construction unit, a wooden board substitute, as well as an economical alternative to concrete blocks, ceiling panels and sound barrier panels.

Moreira et al. [58] studied the performance of building blocks made with the partial replacement of fine aggregates with sawdust from the Dinizia Excelsa Ducke wood species. The blocks were made by replacing fine aggregates with sawdust at $5 \%$ by weight. Two sawdust treatment processes, one comprising the washing of the sawdust in an alkaline solution (lime) and another comprising the immersion of the sawdust in aluminum sulfate were used. The compressive strength results on the $28^{\text {th }}$ day were 1.39 and $3.98 \mathrm{MPa}$ for the two treatment methods respectively. The water absorption results were $13.13 \%$ and $10.40 \%$ respectively. The results showed good performance of the blocks made with aluminum sulphate treated sawdust than those made with alkaline solution treated sawdust. The 28 days compressive strength results of $3.98 \mathrm{MPa}$ for blocks with aluminum sulphate treated sawdust satisfied the Brazilian NBR7173 standard that specifies a minimum compressive average strength of $2.5 \mathrm{MPa}$ for construction blocks. The study showed the potential of producing masonry blocks with 5\% fine aggregates replaced with aluminum sulphate treated Dinizia Excelsa Ducke sawdust.

Adebakin et al. [59] investigated the use of sawdust as a partial replacement 
for sand in the production of hollow sandcrete blocks. The study aimed at reducing the cost of construction materials and lowering the dead loads imposed on particularly high rise buildings and those built on low bearing capacity soils. The investigation showed that replacement of sand by $10 \%$ sawdust resulted in blocks with compressive strength values that almost met the required Nigerian standard specification of $3.5-10 \mathrm{MPa}$ for sandcrete blocks. This $10 \%$ sawdust replacement content also yielded blocks with $10 \%$ weight reduction and $3 \%$ production cost reduction.

Lightweight bricks made from mixes of sawdust to cement ratios of 3:2 and 2:1 were investigated by Zziwa et al. [60]. Bricks measuring $100 \times 100 \times 100 \mathrm{~mm}$ were tested as air-dried samples and as soaked samples after soaking in water at room temperature for 24 hours. The highest compressive strength result of 2.21 MPa was obtained from the dry specimens with sawdust to cement ratio of 3:2. The corresponding compressive strength result for the soaked specimens averaged 1.38 MPa. The low dry compressive strength and the even lower soaked compressive strength indicated that these bricks did not meet the requirement for use in load bearing walls and walls exposed to wet environments. They could, however, be used for internal wall panelling where there was minimum wetting conditions and little or no loading.

A summary of compressive strength results of selected sawdust bricks and blocks are presented in Table 2. These results indicate good performance of sawdust brick/block composites which should give confidence for their increased use in construction.

\subsection{Sawdust in Lightweight Concrete}

\subsubsection{Partial Replacement of Sand with Sawdust in the Concrete Mix}

Osei and Jackson [61] studied the use of sawdust, crushed granite and rapid hardening cement for the production of sawdust concrete. Using a concrete mix of 1:2:4, sawdust was used to replace $25 \%, 50 \%, 75 \%$ and $100 \%$ of sand by volume. The 28 days strength for the respective sawdust replacement proportions were 12.13 MPa, 9.15 MPa, 4.66 MPa and 3.37 MPa. The study established that sawdust can potentially be used as aggregate in the production of non-structural lightweight concrete for use in situations where the compressive strength was not a major requirement. Further analysis of the compressive strength indicated that a sawdust replacement of less than $14 \%$ can produce concrete with a 28 days compressive strength of $20 \mathrm{MPa}$. This is the minimum concrete strength for structural use. Earlier, Bdeir [62] observed that 10\% replacements of sand with sawdust showed an increase of compressive strength from 23.24 to $27.31 \mathrm{MPa}$ between 7 and 28 days indicating that partial replacement of sand with sawdust in concrete can attain the same order of strength as conventional concrete at longer curing periods.

Suliman et al. [63] used sawdust, sand, crushed stones and cement to produce sawdust concrete. A replacement of sand with sawdust in measures of 5\%, 
Table 2. Compressive strength of sawdust blocks or bricks at 28 days.

\begin{tabular}{|c|c|c|c|}
\hline Author and Country & Size and Type & Sawdust Composite Mix & $\begin{array}{c}\text { Compressive } \\
\text { Strength at } 28 \text { Days }\end{array}$ \\
\hline $\begin{array}{l}\text { Ravindrarajah et al. } \\
\text { [52]. } \\
\text { Australia }\end{array}$ & $\begin{array}{l}100 \mathrm{~mm} \text { dia. } \times 200 \\
\text { mmhigh cylinders }\end{array}$ & $\begin{array}{l}\text { Mixes of cement, fly ash, sand, sawdust, } \\
\text { calcium chloride, lime and water with } \\
\text { sawdust contents ranging from } 3 \% \text { to } 12 \%\end{array}$ & $\begin{array}{l}13 \mathrm{MPa} \text { produced from sawdust content of } 12 \% \\
\text { which produced concrete density of } 1520 \mathrm{~kg} / \mathrm{m}^{3}\end{array}$ \\
\hline $\begin{array}{l}\text { Dadzie et al. [53]. } \\
\quad \text { Ghana }\end{array}$ & $\begin{array}{l}100 \times 100 \times 100 \mathrm{~mm} \\
\text { cubes }\end{array}$ & $\begin{array}{l}\text { Sawdust, sand, cement batched by volume to } \\
\text { a mix proportion of 1:6 (cement to sand) at } \\
\text { a constant water cement ratio of } 0.5 \text {. Sand } \\
\text { replaced with } 10 \%, 20 \%, 30 \% \text { and } 40 \% \\
\text { sawdust }\end{array}$ & $\begin{array}{l}3.04 \mathrm{MPa} \text { at } 10 \% \text { replacement. } \\
\text { (greater than the BS } 6073 \text { minimum of } 2.8 \mathrm{MPa} \text { ) }\end{array}$ \\
\hline $\begin{array}{l}\text { Boob [54]. } \\
\text { India }\end{array}$ & $\begin{array}{l}100 \times 100 \times 100 \mathrm{~mm} \\
\text { cubes }\end{array}$ & $\begin{array}{l}1: 4 \text { (cement: sand + sawdust)-sawdust } \\
\text { replacement of } 0 \%, 5 \%, 10 \%, 15 \% \& 20 \% \text {. } \\
1: 6(0 \%, 5 \%, 10 \%, 15 \% \text { \& } 20 \% \text { sawdust } \\
\text { replacement) } \\
1: 8(0 \%, 5 \%, 10 \%, 15 \% \& 20 \% \text { sawdust } \\
\text { replacement) }\end{array}$ & $\begin{array}{l}\text { 4.5 MPa from the } 1: 6 \text { (cement: sand + sawdust) } \\
(85 \% \text { sand }+15 \% \text { sawdust) }\end{array}$ \\
\hline $\begin{array}{l}\text { Zziwa et al. }[60] . \\
\text { Uganda }\end{array}$ & $\begin{array}{l}50 \times 50 \times 50 \mathrm{~mm} \text { and } 100 \\
\times 100 \mathrm{~mm} \text { cubes }\end{array}$ & $\begin{array}{l}\text { Both sizes made with sawdust to cement } \\
\text { ratios of 3:2 and 2:1 }\end{array}$ & $\begin{array}{l}\text { Mean compressive strength of } 1.61 \mathrm{MPa} \text { and } 1.99 \\
\mathrm{MPa} \text { for } 50 \times 50 \times 50 \mathrm{~mm} \text { blocks with sawdust to } \\
\text { cement ratios of 3:2 and 2:1 respectively; and } 1.78 \\
\mathrm{MPa} \text { and } 2.21 \mathrm{MPa} \text { for } 100 \times 100 \mathrm{~mm} \text { blocks with } \\
\text { sawdust to cement ratios of } 3: 2 \text { and 2:1 respectively }\end{array}$ \\
\hline $\begin{array}{l}\text { Turgut and Algin [57]. } \\
\text { Turkey }\end{array}$ & $105 \times 90 \times 75 \mathrm{~mm}$ blocks & $\begin{array}{l}\text { Mix of cement, water, and three } \\
\text { combinations of Limestone powder waste } \\
\text { (LPW) and wood sawdust waste (WSW). } \\
0 \%, 10 \%, 20 \% \text { and } 30 \% \text { WSW replacement } \\
\text { was used in the WSW-LPW combination }\end{array}$ & $\begin{array}{l}0 \%, 10 \%, 20 \% \text { and } 30 \% \text { WSW replacements } \\
\text { yielded } 24.5,16.6,11 \text { and } 7.2 \mathrm{MPa} \text { respectively }\end{array}$ \\
\hline $\begin{array}{l}\text { Kupolati et al. }[50] \text {. } \\
\text { South Africa }\end{array}$ & $\begin{array}{l}100 \times 100 \times 100 \mathrm{~mm} \\
\text { cubes }\end{array}$ & $\begin{array}{l}\text { Water, hardener, cement, sand and sawdust } \\
\text { at } 13 \%, 2 \%, 11 \%, 73 \% \text { and } 1 \% \text { respectively }\end{array}$ & $\begin{array}{l}\text { The average optimum compressive strength for } \\
\text { brick cubes }(100 \times 100 \times 100 \mathrm{~mm}) \text { at the } \\
\text { laboratory was } 6.10 \mathrm{MPa} \text {. A minimum value of } 4.0 \\
\mathrm{MPa} \text { is specified for solid masonry units in } \\
\text { masonry walls [51] }\end{array}$ \\
\hline
\end{tabular}

$10 \%$ and $15 \%$ of the total sand volume was investigated. The resulting compressive strength values at 28 days were $50.06 \mathrm{MPa}, 41.48 \mathrm{MPa}$ and $34.7 \mathrm{MPa}$ respectively. The optimum design for producing sawdust concrete was established at $10 \%$ sawdust replacement content. The study further showed that the sawdust concrete was free from any harmful health contaminants.

A study by Oyedepo et al. [64] showed that the compressive strength values obtained with sawdust content equal to or greater than $25 \%$ did not conform to the Nigerian minimum requirement of $17 \mathrm{MPa}$ for light weight concrete. The concrete mix ratio of 1:2:4 was prepared using water/cement of 0.65 , with $0 \%$, $25 \%, 50 \%, 75 \%$ and $100 \%$ sawdust as partial replacement for fine sand. Compressive strength values for the $25 \%, 75 \%$ and $100 \%$ sawdust replacement percentages were 14.15 $\mathrm{MPa}, 12.96 \mathrm{MPa}$ and $11.93 \mathrm{MPa}$ respectively. Consequently, this study observed that using sawdust in a proportion greater than $25 \%$ was detrimental to strength and density properties of concrete. A further suggestion was that use of $0 \%$ to $25 \%$ sawdust content as partial replacement in concrete 
would not adversely affect concrete strength.

Nathan [65] showed that sawdust is a potential material for preparation of light weight concrete. By using cement, fine aggregate, coarse aggregate, water and sawdust, a conventional control mix was prepared with mix proportions of 1:1.5:3. Replacement of fine aggregate with sawdust was done at $0 \%, 5 \%, 10 \%$, $15 \%$ and $20 \%$. The average compressive strength values recorded at 28 days were 29.33 $\mathrm{MPa}$, 27.7 $\mathrm{MPa}$, 26.37 $\mathrm{MPa}, 24.15 \mathrm{MPa}$ and 22.67 $\mathrm{MPa}$ respectively. The respective tensile strengths were $2.08 \mathrm{MPa}, 1.82 \mathrm{MPa}, 1.69 \mathrm{MPa}, 1.49 \mathrm{MPa}$ and 1.41 MPa. Using a similar mix design an investigation by Tilak et al. [2] showed lower compressive strengths of $24.13 \mathrm{MPa}, 15.55 \mathrm{MPa}, 11.11 \mathrm{MPa}$ and $8.13 \mathrm{MPa}$, when fine aggregate was replaced with sawdust at proportions of $10 \%, 20 \%, 50 \%$ and $100 \%$ respectively. These two studies indicate potential use of sawdust in structural concrete when the proportion of sawdust replacement of sand does not exceed $10 \%$.

Chitra and Hemapriya [66] used a mix proportion of 1:1.60:2.78 to reiterate the possibility of using sawdust as an alternative to sand with optimum strengths obtained at $15 \%$ replacement of sand with sawdust. The compressive strength values obtained at 28 days were $25.1 \mathrm{MPa}, 24.2 \mathrm{MPa}, 23.75 \mathrm{MPa}$ and $17.54 \mathrm{MPa}$ when fine aggregate was replaced with sawdust at $0 \%, 5 \%, 10 \%, 15 \%$ respectively.

Sawant et al. [67] investigated sawdust concrete made from a 1:1.62:2.83 mix proportion that included cementitious metakaolin as an admixture, meant to provide good bonding between sawdust and other concrete ingredients. Partial replacement of sand with sawdust in measures of $0 \%, 5 \%, 10 \%, 15 \%, 20 \%$ and $25 \%$ was done in the investigation. The resulting compressive strength values were 24.4 MPa, 21.11 MPa, 12.45 MPa, 10.07 MPa, 7.25 MPa and 5.12 MPa respectively, indicating good strength for sawdust content of less than $10 \%$.

A study by Awal et al. [68] investigated sawdust concrete specimens made with cement to sawdust ratios of 1:1, 1:2 and 1:3 by volume. The respective compressive strength results at the age of 28 days for the aforementioned cement to sawdust mix proportions were 18.65 $\mathrm{MPa}, 17.20 \mathrm{MPa}$ and 12.80 MPa. The strength of the sawdust concrete increased with increase in curing age. However, the strength and the recorded modulus of elasticity decreased with the increasing amount of sawdust in the mix.

Sawdust concrete from 1:1:2 and 1:1.5:3 mixes, with sawdust replacing the coarse aggregate, was investigated by Ogundipe and Jimoh [3]. The 28 days compressive strength results were 18.33 and $8.78 \mathrm{MPa}$ respectively, while their 28 days flexural strengths were 1.71 and $1.33 \mathrm{MPa}$ respectively. The 28 days water absorption of the mixes were $5.69 \%, 8.97 \%, 8.29 \%, 7.83 \%$ and $11.11 \%$ with respective 28 days linear shrinkages of $0.67 \%, 0.50 \%, 1.83 \%, 1.83 \%$ and $1.95 \%$.

Sojobi [69] observed that sawdust wastes and laterite as alternative fine aggregate and cementitious material respectively could be used to produce eco-friendly lightweight interlocking concrete paving units (ICPUs). Consequently, Sojobi et 
al. [70] produced ultra-lightweight green interlocking paving units using the same materials. With an optimum $10 \%$ sawdust content and after 90 days water curing, the paving units attained a compressive strength of $16.6 \mathrm{MPa}$ and exhibited a skid resistance of 64.5 pendulum test value (PVT). The strength results exceeded the minimum requirements of 3.45 to $15 \mathrm{MPa}$ for pedestrian traffic and non-load bearing concrete applications.

The possibility of using reinforcement in sawdust concrete was studied by Olutoge [71]. This study demonstrated that replacing less than $25 \%$ of sand by sawdust in reinforced concrete yielded results that satisfied the characteristic strength requirements for structural use of concrete as specified in the BS 8110, 1997.

Figure 2 shows an overview of the 28 days sawdust concrete compressive strength results in relation to partial replacement of sand by sawdust in various concrete mixes. Data from Figure 2 indicates that concrete mixes with sawdust content of $5 \%$ to $15 \%$ as replacement for sand can generally produce concrete with compressive strength values exceeding $15 \mathrm{MPa}$, which is suitable for lightweight structural applications as recommended by Neville [72].

Figure 2 further shows that mixes with sawdust content of between $5 \%$ and $10 \%$ as replacement for sand can produce concrete with compressive strength values higher than $20 \mathrm{MPa}$. These mixes could thus be used in structural applications in line with the ASTM C330/C330M-09 [73] recommendations. Further it is noted that compressive strength significantly decreases with increased sawdust beyond $15 \%$ sand replacement content.

A scatter plot showing the effect of sand replacement by sawdust on the compressive strength of sawdust concrete is presented in Figure 3. The average compressive strength results give an exponential relationship with a good correlation value, i.e. $\mathrm{R}^{2}=0.8017$. This relationship can be expressed as

$$
f_{c}=25.944 \mathrm{e}^{-0.015 \lambda}
$$

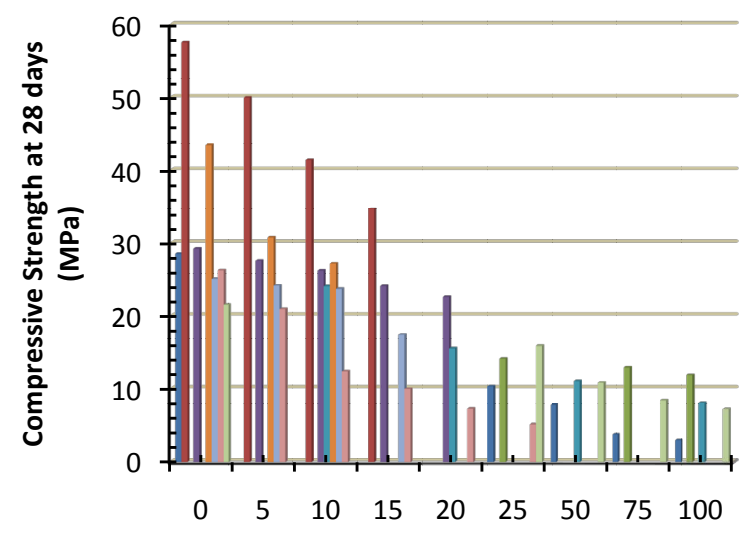

\author{
- Osei \& Jackson 2016 \\ - Suliman et al 2019 \\ Oyedepo 2014 \\ nathan 2018 \\ Tilak 2018 \\ - Bdeir 2012 \\ - Chitra \& Hemapriya 2018 \\ - Sawant et al 2018 \\ Olutoge 2010
}

Sand Replacement by Sawdust (\%)

Figure 2. Compressive strength of sawdust concrete in relation to the sawdust replacement component. 


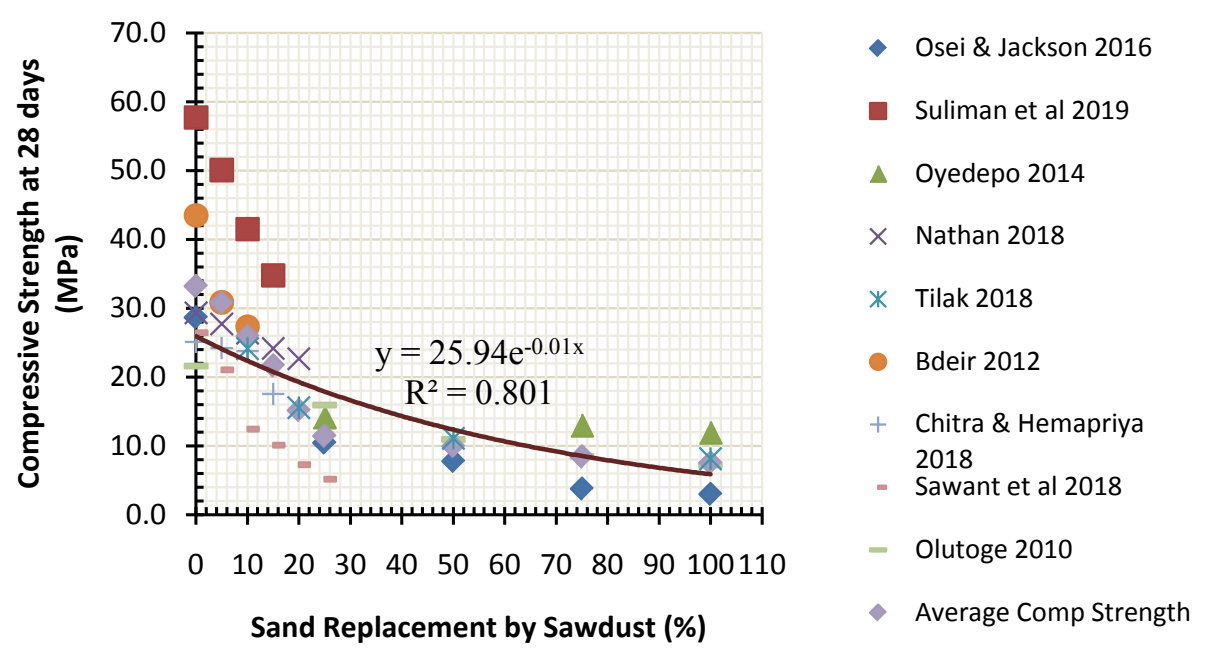

Figure 3. Scatter plot of sand replacement by sawdust versus compressive strength of sawdust concrete.

where:

$f_{c}$ is the 28-day compressive strength in MPa.

$\lambda$ is the percentage sand replacement by sawdust.

It is noted from Equation (1) that the optimum content of sand replacement by sawdust required to produce structural concrete with a compressive strength of $20 \mathrm{MPa}$ is $17 \%$. Sawdust content above this proportion results in sawdust concrete with compressive strengths lower than $20 \mathrm{MPa}$.

Figure 4 illustrates a decrease in flexural strength with increase in the sawdust content. This is particularly evident from studies by Sawant et al. [67] and [74].

\subsubsection{Sawdust Concrete with Sawdust as One of the Main Constituents} Apart from partial replacement of sand with sawdust, other studies have also been made where sawdust is one of the main constituents of the concrete mix. Comparisons of compressive, split tensile and flexural strength results of sawdust concrete from selected literature are shown in Table 3. The tabulated results indicate reduction in compressive, flexural and split tensile strengths with increase in the amount of sawdust in the concrete mix. It is also noted from $\mathrm{Ta}$ ble 3 that the 1:1:2 and the 1:1:1 mixes produce lightweight concrete with good compressive strength results.

\subsubsection{Partial Replacement of Cement with Sawdust Ash (SDA) in the Concrete Mix}

Udoeyo and Dashibil [78] and Marthong [79] investigated sawdust ash (SDA) concrete by replacing ordinary Portland cement (OPC) with SDA. The studies established that with a $10 \%$ SDA replacement it was possible to attain a design strength of $20 \mathrm{MPa}$ at 28 days, which is comparable with the strength attained by conventional concrete at longer curing periods. Marthong [79] however, noted that inclusion of SDA as partial replacement for cement tended to reduce the durability of concrete when exposed to sulphate environment. Later Obilade [80] 


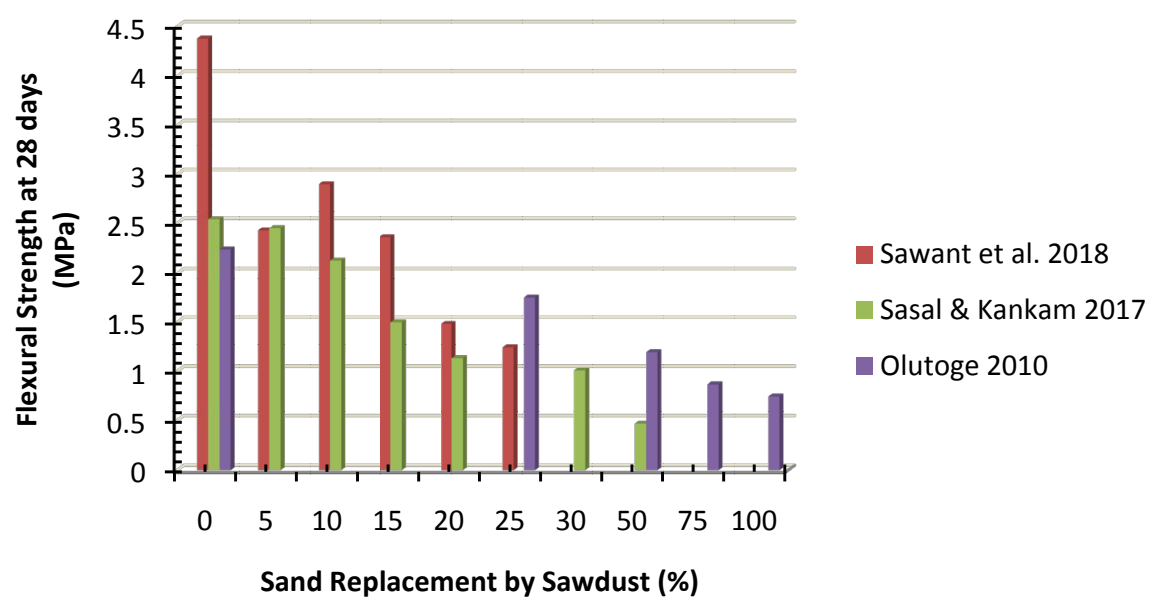

Figure 4. Flexural strength test of sawdust concrete in relation to sawdust content.

Table 3. Compressive, flexural and split tensile strengths resulting from various sawdust mix composites.

\begin{tabular}{ccccc}
\hline Author (s) & $\begin{array}{c}\text { Mix } \\
\text { (cement-sand- } \\
\text { sawdust) }\end{array}$ & $\begin{array}{c}\text { Compressive } \\
\text { Strength at 28 days } \\
(\mathbf{M P a})\end{array}$ & $\begin{array}{c}\text { Flexural Strength } \\
\text { at 28 days } \\
(\mathrm{MPa})\end{array}$ & $\begin{array}{c}\text { Split Tensile } \\
\text { Strength at 28 days } \\
(\mathbf{M P a})\end{array}$ \\
\hline $\begin{array}{c}\text { Ogundipe and } \\
\text { Jimoh [75] }\end{array}$ & $1: 1: 2$ & 18.33 & 1.71 & - \\
Huseien et al. & $1: 1.5: 3$ & 8.78 & 1.33 & - \\
[76] & $1: 1: 1$ & 14.00 & 4.00 & 4.00 \\
& $1: 1: 2$ & 6.00 & 2.90 & 2.2 \\
Awal et al. [68] & $1: 1: 3$ & 4.00 & 0.50 & 0.40 \\
& $1: 1^{*}$ & 18.65 & 2.75 & 2.06 \\
Ok7] & $1: 2^{*}$ & 17.20 & 2.20 & 1.95 \\
& $1: 3^{*}$ & 12.80 & 1.90 & 1.30 \\
& $1: 1: 1$ & 10.861 & 2.32 & 1.98 \\
& $1: 2: 2$ & 9.126 & 2.09 & 1.71 \\
\hline
\end{tabular}

${ }^{*}$ Cement to sawdust mix ratio; - No data available.

showed that SDA led to the attainment of 28 days compressive strengths of between 21.02 and $19.05 \mathrm{MPa}$ at $5 \%$ to $15 \%$ sawdust ash replacement respectively. The $5 \%$ to $15 \%$ SDA content was thus considered as the optimum SDA replacement for cement as SDA content of above 15\% significantly reduced the concrete compressive strength. This investigation recommended the evaluation of the durability of concrete made with SDA as partial replacement for cement.

Dhull [81] partially replaced the mass of cement by amounts of 5\%,10\%,15\% and $20 \%$ in a 1:1:2 concrete mix ratio. The 28 days strength of the $5 \%$ and $10 \%$ replacement contents resulted in compressive strength results of 32.44 and 30.24 MPa respectively. Replacement of cement with higher contents of SDA beyond $10 \%$ produced concrete with compressive strengths lower than the strength of the control mix. 
Using the Scheffe's Simpexfive component design ratio of 0.5:0.95:0.05:2.25:4 i.e., water: cement: sawdust ash: sand: granites, a study by Onwuka et al. [82] produced SDA concrete with an optimum compressive strength result at 28 days of 20.44 MPa. The study concluded that sawdust concrete can suitably be used as a building material in construction industry.

Fapohunda et al. [83] showed that, wood waste, either in the form of SDA, or wood aggregate, or sawdust; can be incorporated into an appropriate concrete mix design which can yield structural concrete that satisfies building requirements. The SDA content must however, not exceed 20\%. Concrete incorporating SDA is known to exhibit good durability properties against most of the process that degrade concrete in its service life. However its durability is compromised when it is exposed to carbonation and sulphate attack. Mangi et al. [84] also noted the need to investigate the durability of high-strength concrete developed with SDA and its performance in aggressive alkaline and acidic environments.

An investigation by Raheem et al. [85] further notes that SDA concrete becomes less workable as the SDA content increases. This indicates that SDA has a higher water demand compared with ordinary Portland cement. The study observed that $5 \%$ SDA was the optimum substitution content that produced SDA concrete strength gain comparable to the control mix which had no SDA content.

The compressive strength values of SDA concrete in Figure 5 show similar trend to those in Figure 2 in terms of decreasing strength with increase in SDA. Figure 5 further indicates that concrete with $5 \%$ to $15 \%$ SDA as replacement for cement could be used to produce concrete with compressive strength values greater than $20 \mathrm{MPa}$. This concrete can be used for structural applications.

\subsection{Effect of Sawdust Composites on Thermal Properties of Construction Units}

Thermal insulation materials and systems are used to reduce heat flow transmission. The thermal conductivity and thermal transmittance indicate the thermal

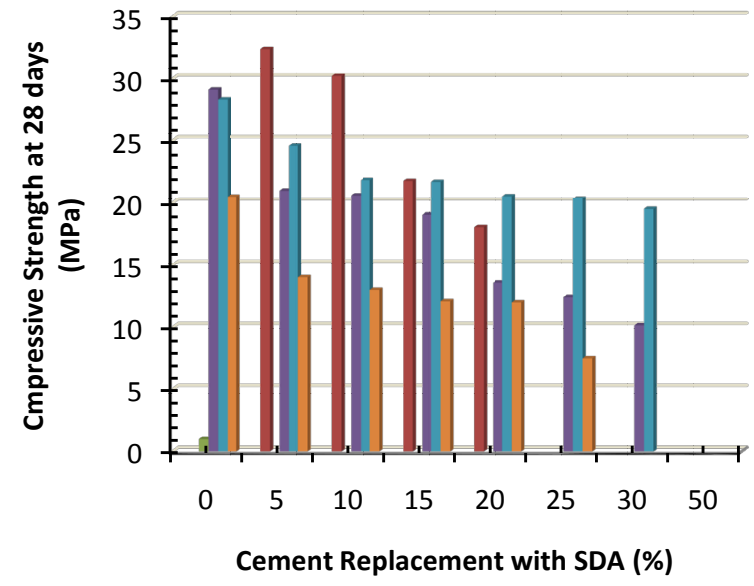

Dhull (2017)

- Obilade (2014)

Chowdhury et. al. (2015)

Raheem et. al. (2012)

Figure 5. Compressive strength of SDA concrete. 
insulation performance of such materials. Construction materials with a thermal conductivity of less than $0.07 \mathrm{~W} / \mathrm{mK}$ are considered as thermal insulators [86].

Thermal conductivities for timber are favourable compared with other materials used in buildings. They vary slightly with different densities, moisture contents and species, the lower densities having lower conductivities. Meyer [24] argues that one primary advantage of waste wood aggregate, such as sawdust and shavings, is the low weight and high thermal insulation value of the material.

Sawdust concrete made from cement, sawdust and sand mixed in the ratios 1:1:1, 1:2:1 and 1:3:1 respectively have shown that the 1:3:1 mix ratio exhibited lower thermal conductivity when compared with the other two mixes. This reduction in the heat transfer through the 1:3:1 mix was attributed to the increased sawdust content in this mix compared with the other two [76] [87].

Salih and Kzar [88] used a combination of pre-treated reed and sawdust as partial replacement for natural sand in a 1:2.5 (cement:sand) mix. The reed and sawdust were pre-treated by soaking them in boiling water to which lime amounting to $20 \%$ of the weight of reed or sawdust was added. The soaking treatment was done to reduce harmful soluble carbohydrates, tannins, waxes and raisins. The replacement contents were an equal combinations of sawdust and reed in $10 \%, 20 \%, 30 \%$, and $40 \%$ proportions. For example, the $10 \%$ replacement comprised 5\% sawdust and 5\% reed. A water cement ratio was kept at 0.4 for all the mixes. The values of 28 days oven dry densities ranged between 2060 and $1693 \mathrm{~kg} / \mathrm{m}^{3}$ the high values relating to the density of the control mix. The lower density values were obtained for the $40 \%$ (i.e. $20 \%$ sawdust and $20 \%$ reed) sand replacement content. The thermal conductivity significantly decreased from 0.745 to $0.222 \mathrm{~W} / \mathrm{mK}$ for the control and the $40 \%$ sand replacement mix respectively.

A study by Sindanne et al. [89] involving earth blocks stabilized by cement, sawdust and lime showed increase in thermal conductivity with increase in cement and lime as stabilising agents. However stabilisation with sawdust decreased the thermal conductivity of the blocks. Sawdust stabilised blocks were thus observed to exhibit increased thermal resistance when compared with the cement or lime-stabilised blocks. The results from this study are summarised in Table 4.

Ogundipe and Jimoh [75] replaced coarse aggregate with sawdust in four mixes, namely 1:1:2, 1:1.5:3, 1:2:4, 1:3:6 and 1:4:8. Respective conductivity results measured after a 28 days curing period were $0.229,0.232,0.229,0.223$ and 0.176 $\mathrm{W} / \mathrm{mK}$. The results indicate progressive reduction in thermal conductivity with increase in the sawdust content. This trend was also noticed in studies done by AbdulAmeer [90], Salih and Kzar [88] and Cheng et al. [91], presented in Figure 6.

Figure 6 further shows that sawdust concrete exhibits lower thermal conductivity compared with the conventional concrete $(0 \%$ sawdust content in this case). The reduction in thermal conductivity with increase in sawdust, a lightweight 
Table 4. Thermal conductivity of stabilised earth blocks (W/mK) - after Sindanne et al. [89].

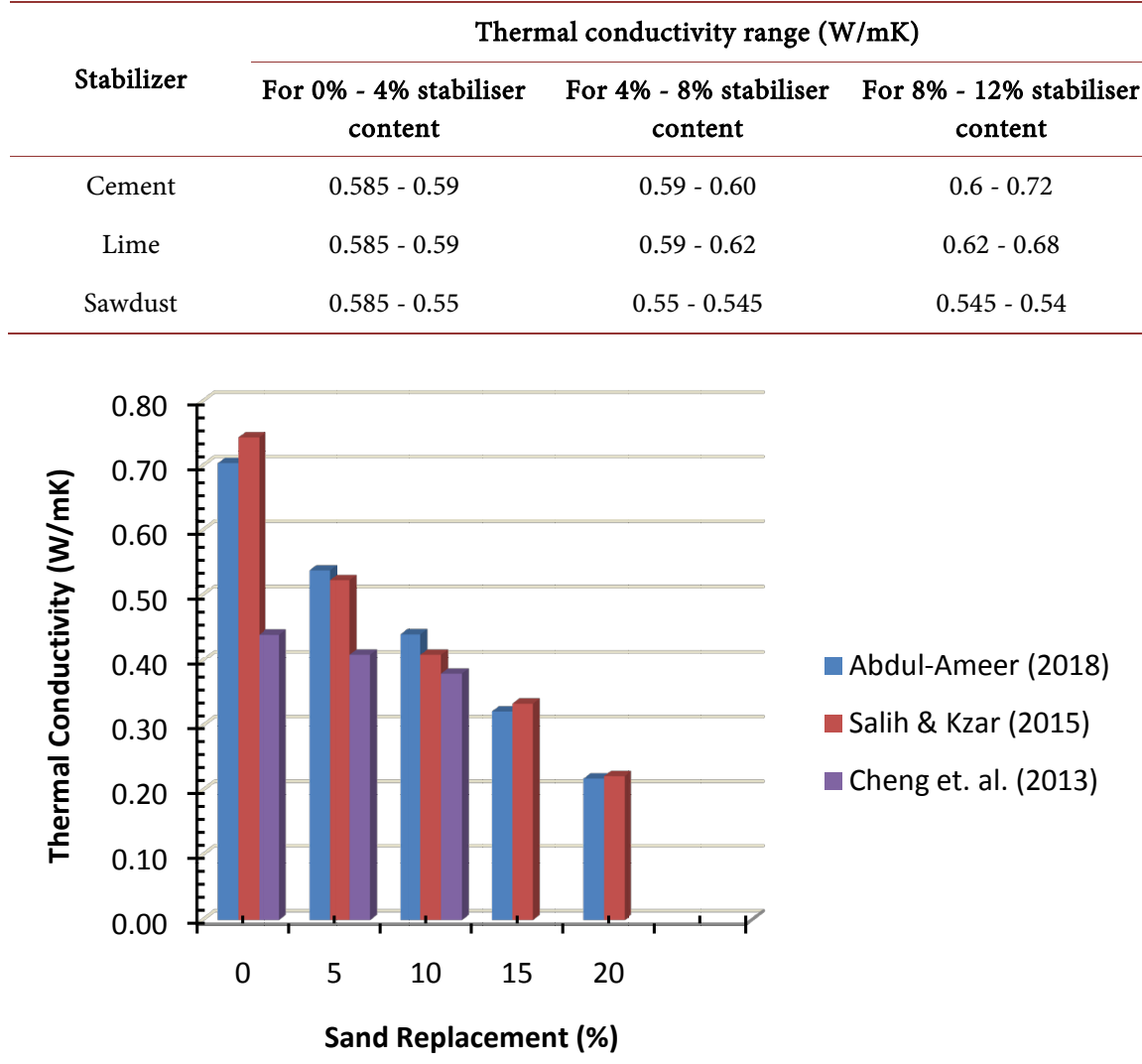

Figure 6. Thermal conductivity of sawdust concrete in relation to the amount of sawdust.

aggregate, is in agreement with findings of Asadi et al. [92]. Lightweight aggregates, not only reduces the density, but also the thermal conductivity of concrete. Conventional concrete with a density of between 2100 and $2400 \mathrm{~kg} / \mathrm{m}^{3}$ has a thermal conductivity of between 1.40 and $1.75 \mathrm{~W} / \mathrm{mK}$ [93] [94]. Thus addition of sawdust in the concrete mix significantly reduces the thermal conductivity of the resulting lightweight concrete.

The thermal conductivity values shown in Figure 6 also satisfy the requirements of ASTM C332-09 [95] which stipulates that the maximum average thermal conductivity for concrete made from lightweight aggregates should be 0.43 $\mathrm{W} / \mathrm{mK}$ for oven dry concrete that has a density of $1440 \mathrm{~kg} / \mathrm{m}^{3}$ at 28 days.

\subsection{Effect of Sawdust Composites on Acoustic Properties in Construction Units}

\subsubsection{Sound Absorption}

Noise pollution is considered one of the four major environmental hazards that include air, water and solid waste pollution. Sound absorbing materials therefore play an important role in mitigating noise pollution effects on human health such as hearing loss and stress [96]. Low frequency noise, particularly that with a frequency range of $10 \mathrm{~Hz}$ to $100 \mathrm{~Hz}$ poses a special environmental noise that can 
cause heightened distress in people that are sensitive to its effects [97]. Sound absorbing materials reduce acoustic energy of a sound wave as the wave passes through it. One way of evaluating the performance of sound absorbing materials is by measuring the sound absorption coefficient, defined as the measure of the acoustic energy absorbed by the material upon incidence of the energy wave [98] [99].

An absorption coefficient of 0.00 entails that no sound has been absorbed whereas a sound absorption coefficient close to 1.00 for a sound frequency range of 125 to $4000 \mathrm{~Hz}$ entails good sound absorption [98] [100].

Wood is the most frequently used material for sound absorption in auditoria. When used in various forms in combination with complimentary sound absorptive materials it can provide optimum sound absorption properties. In this regard, wood in the form of sawdust incorporated in concrete or mortar and other related construction elements has been found to be effective in sound adsorption.

Kang et al. [101] studied rice hull-sawdust composite boards for sound adsorption in construction. The target densities for the boards were 400, 500,600, and 700 $\mathrm{kg} / \mathrm{m}^{3}$. The percentage by weight combinations of rice-hull/sawdust/phenol-resin mixes were 10/80/10, 20/70/10, 30/60/10 and 40/50/10 respectively. The sound absorption characteristics of these boards were compared with those of commercial gypsum board and fiberboard. The sound adsorption coefficients of the composite board were about 0.20 at $500 \mathrm{~Hz}, 0.40$ at $1000 \mathrm{~Hz}$, and $0.40-0.55$ at over $1000 \mathrm{~Hz}$. The sound absorption coefficient of the composite board was found to be two times higher than that of the gypsum board with an $11 \mathrm{~mm}$ thickness, especially at a frequency of $1000 \mathrm{~Hz}$. The composite boards further showed higher sound adsorption coefficients than the commercial gypsum boards over the frequency range of 500 to $4000 \mathrm{~Hz}$. The overall results showed that the rice hull-sawdust composite boards could be used as a replacement material for sound absorbing purposes in non-structural construction applications, such as ceilings, wall sheathing and interior wall surfaces.

Tiuc et al. [100] studied sound absorption of two products made from two waste materials namely, recycled rubber and sawdust. One product comprised of recycled rubber particles and 15\% polyurethane binder. The other one comprised sawdust and 30\% polyurethane material. Both products were $15 \mathrm{~mm}$ thick. For the frequency range of 100 to $1000 \mathrm{~Hz}$ both products showed similar sound absorption coefficient characteristics. However, for the higher frequency range of 1000 to $3150 \mathrm{~Hz}$ the sample with rubber particles had better sound absorption properties.

Materials made from sawdust and recycled rubber granules were tested for acoustic performance and compared with the existing acoustic products on the market, namely glass wool and flexible polyurethane foam. The sound absorption coefficient was experimentally evaluated over a frequency range of 100 to $3200 \mathrm{~Hz}$. The results showed that composite materials made from sawdust and 
rubber granules had better acoustic properties than the existing products, particularly at frequencies below $1600 \mathrm{~Hz}$. Sound absorption coefficient measured for material made with sawdust and $30 \%$ polyurethane binder had a minimum value of 0.65 in the frequency range of 300 to $3150 \mathrm{~Hz}$. A maximum sound absorption coefficient of 0.979 was recorded at the frequency of $2000 \mathrm{~Hz}$ [99].

Tiuc et al. [102] further compared the sound absorption of products made from 100\% Flexible Polyurethane Foam (100-FPF) and those made with 50\% fir sawdust and 50\% Flexible Polyurethane Foam (50-FPF). The 100-FPF product exhibited effective sound absorption characteristics for the 100 to $1700 \mathrm{~Hz}$ frequency range. This product recorded a maximum sound absorption coefficient value of 0.86 at a frequency of $1700 \mathrm{~Hz}$. The 50-FPF product exhibited effective sound absorption characteristics for the 100 to $700 \mathrm{~Hz}$ frequency range, recording a maximum sound absorption coefficient value of 0.89 at a frequency of 700 Hz. This study also observed that composite porous materials exhibited complex sound absorption characteristics.

Table 5 presents sound absorption characteristics of various types of materials. It is clearly noted from this table that sawdust composites have better sound absorption capacity over materials such ordinary wood, conventional concrete and brick work.

Table 5. Sound absorption properties of some common building materials and those incorporating sawdust.

\begin{tabular}{|c|c|c|c|}
\hline Author & Material & $\begin{array}{l}\text { Sound Absorption } \\
\text { Coefficient }\end{array}$ & Frequency $(\mathrm{Hz})$ \\
\hline \multirow[t]{3}{*}{$\begin{array}{c}\text { Dance and Shield [103], } \\
\text { Vorländer [104] }\end{array}$} & Smooth unpainted concrete & $0.01,0.02,0.05$ & $\begin{array}{l}125,1000 \text { and } \\
4000 \text { respectively }\end{array}$ \\
\hline & Rough concrete & $0.02,0.03,0.07$ & - Ditto - \\
\hline & $\begin{array}{l}\text { Brick wall, stuccoed } \\
\text { with rough finish }\end{array}$ & $0.03,0.04,0.07$ & - Ditto - \\
\hline \multirow[t]{3}{*}{ Vorländer [104] } & $\begin{array}{l}\text { Brickwork, with facing brick of } \\
\text { dimensions } 230 \times 50 \times 55 \mathrm{~mm}\end{array}$ & $0.04,0.35,0.36$ & - Ditto - \\
\hline & Thin plywood panelling & $0.42,0.08,0.06$ & - Ditto - \\
\hline & Solid wooden door & $0.14,0.08,0.10$ & - Ditto - \\
\hline Tiuc et al [105] & Sawdust and recycled & 0.65 & $300-3150$ \\
\hline 11uc el all $[105]$ & Rubber granules & 0.979 & 2000 \\
\hline Tiuc et al. [100] & $\begin{array}{l}\text { Sawdust with } 30 \% \\
\text { polyurethane binder }\end{array}$ & $0.1-0.89$ & $450-1600$ \\
\hline Tiuc et al. [102] & $\begin{array}{l}\text { Composite material made of } \\
50 \% \text { Flexible Polyurethane } \\
\text { Form and } 50 \% \text { fir sawdust }\end{array}$ & $0.09-0.89$ & $100-800$ \\
\hline Kang et al. [101] & $\begin{array}{l}\text { Rice hull-sawdust composite } \\
\text { boards }\end{array}$ & $\begin{array}{c}0.2 \\
0.4 \\
0.40-0.55\end{array}$ & $\begin{array}{c}500 \\
1000 \\
\text { Above } 1000\end{array}$ \\
\hline
\end{tabular}




\subsubsection{Sound Insulation}

Sound absorption products absorb echoes inside a room, thereby preventing sound from bouncing around the room. Sound-insulating materials, on the other hand block or stop sound waves from traveling to adjacent spaces.

Timber studded partitions for offices can be designed to obtain any degree of sound insulation required from the barest minimum. Knowledgeable design and attention to detail can result in a very high sound insulation within minimum overall thickness [106].

Chung et al. [107] established that lightweight timber based floor/ceiling systems (LTFSs) can have superior impact sound insulation to that of concrete slab based systems. Examples of such systems include vibration isolation/damping features, such as rubber ceiling batten clips, glass fibre wool, and a sand-sawdust mixture layer. The inclusion of the sand-sawdust layer was found to provide effective vibration damping and thus sound insulation of the whole composite structure over a wide frequency range. Later Chung et al. [35] used a mathematical model to predict the vibration of lightweight timber-framed floor/ceiling systems (LTFSs) caused by mechanical excitation. This study consolidated the earlier findings of the good sound insulating properties of the sand-sawdust layer in LTFSs. The theoretical model and the experimental measurements showed that the sand-sawdust layer effectively dampens the vibration in the frequency range of between 10 and $200 \mathrm{~Hz}$.

Emms et al. [108] examined several problems surrounding lightweight floors, one being the inadequate impact insulation capacity in the low-frequency region of 16 to $250 \mathrm{~Hz}$. The use of a sand/sawdust mix as an infill in battened cavities of these lightweight floors provides good impact insulation results, attributed to a combination of added mass, more damping capacity and floor stiffness.

Chathurangani et al. [109] studied a combination of sawdust and coconut coir fiber for use as noise reducing wall surface materials. The study verified the potential use of these materials for effective noise reduction. From this study, the noise reduction co-efficient, a ratio between the reduction levels of noise to the intensity of incident sound, values obtained for sawdust and coir fiber tiles ranged from 0.1 to 0.5 . Later a study done in Indonesia proved that using panels made from similar materials had good acoustical performances and could be used for wall layering in noisy urban housings [110].

\section{Future Trends}

Sawdust is a recyclable waste and a raw material that is readily available and easily accessible in many timber producing countries. It can be collected and transported at minimal cost and energy when compared with the cost and energy required in exploiting natural resources. Value addition to this waste by incorporating it in the production of construction composites will address the quest for eco-friendly and energy efficient materials in building and construction, contribute to a pollution-free environment and create employment. 
Research and development of sawdust construction composites is, therefore, likely to increase in the nearby future. Possible future research focus and development includes producing versatile sawdust construction composite materials that are more robust, durable, lightweight, energy efficient, cost effective and safe for civil engineering infrastructure, than is obtaining presently. Novel eco-friendly and energy efficient construction composites that are expected to attract research and construction interests include those made from cement-sawdust admixtures, bitumen-sawdust admixtures and polymer-sawdust admixtures. Development of these novel sawdust composites will make a huge contribution to the science of alternative construction materials and greatly influence the reformulation of construction material specifications and standards.

Other potential future uses of sawdust composites in construction include their use as construction formwork and as lightweight roofing tiles. These composites also have the potential of replacing conventional air-conditioning in handling urban heat and thermal discomfort, with the added benefits of energy conservation and climate change mitigation.

\section{Conclusions}

Literature shows that many timber producing countries generate more than 2 million $\mathrm{m}^{3}$ of sawdust annually. In developing countries, this material is often indiscriminately disposed of by open dumping and open burning, posing a huge environmental challenge. Various studies on the use of sawdust in construction, aimed at mitigating this sawdust environmental challenge, have been reviewed in this paper. The reviewed studies include the use and potential use of sawdust and sawdust ash in sawdust construction composites like particleboards, bricks, blocks and lightweight concrete.

Particleboards incorporating sawdust can exhibit modulus of elasticity values of more than $2100 \mathrm{MPa}$, thickness swelling of not more than 15\% and acceptable water absorption characteristics that satisfy international specifications. Sawdust and sawdust ash can be incorporated as part of the raw materials to produce bricks and blocks that satisfy building specifications for masonry wall units and paving bricks. Lightweight concrete for both structural and non-structural works can be produced with sawdust or sawdust ash forming part of or as one of the main concrete ingredients. Sawdust construction composites are also attractive for their low thermal conductivity, high sound absorption and good sound insulation characteristics.

It is however noted from literature that increased sawdust proportions in the sawdust construction composites adversely affect the mechanical and physical characteristics of the produced composites. Replacing part of conventional sand in a concrete mix with sawdust proportions ranging between $5 \%$ and $15 \%$ can produce good lightweight structural concrete with compressive strength values greater than $20 \mathrm{MPa}$. Analysis of the collected data gives a relationship between the compressive strength of sawdust concrete $\left(f_{c}\right)$ and sand replacement by 
sawdust content $(\lambda)$ as $f_{c}=25.944 \mathrm{e}^{-0.015 \lambda}$. This relationship gives an optimum $\lambda$ value of $17 \%$ for producing structural concrete with $f_{c}$ of $20 \mathrm{MPa}$.

Replacing cement with sawdust ash (SDA) proportions of $5 \%$ to $15 \%$ also produces concrete with compressive strengths greater than $20 \mathrm{MPa}$. Higher sawdust and SDA proportions than these significantly reduce the sawdust concrete strength. Replacing $10 \%$ to $30 \%$ of the sand used in the manufacture blocks and bricks with sawdust can also yield sawdust bricks and blocks with compressive and water absorption characteristics that satisfy international specifications.

Increased use of sawdust in construction will greatly contribute to construction sustainability related to the development and use of environmental friendly and green building materials. Additionally, using sawdust composites in construction would contribute to conservation of non-renewable construction resources, reduction of energy as well as $\mathrm{CO}_{2}$ emissions from the exploitation of natural construction materials. All this will ultimately greatly contribute to climate change mitigation. Thus sawdust composites have a market as well as environmental mitigation value. Developing countries should not, therefore, regard sawdust as a waste, but as a valuable by-product with increased potential use in the construction industry.

\section{Acknowledgements}

The authors gratefully acknowledge the support from Copperbelt University, Kitwe, Zambia.

\section{Conflicts of Interest}

The main author and the co-author (listed as authors) met authorship criteria and certify that they have participated sufficiently in the work to take public responsibility for the content and participation in the concept, design, analysis and writing of the manuscript. Furthermore, each author certifies that this material or similar material has not been submitted to another journal for publication.

\section{References}

[1] Kumar, D., Singh, S., Kumar, N. and Gupta, A. (2014) Low Cost Construction Material for Concrete as Sawdust. Global Journal of Research in Engineering, 14, 33-36.

[2] Tilak, L.N., Santhosh Kumar, M.B., Manvendra, S. and Niranjan (2018) Use of Saw Dust as Fine Aggregate in Concrete Mixture. International Research Journal of Engineering and Technology (IRJET), 5, 1249-1253.

[3] Ogundipe, O. and Jimoh, Y. (2012) Strength-Based Appropriateness of Sawdust Concrete for Rigid Pavement. Advanced Materials Research, 367, 13-18. https://doi.org/10.4028/www.scientific.net/AMR.62-64.11

[4] Adu, S., Adu, G., Frimpong-Mensah, K., Antwi-Boasiako, C., Effah, B. and Adjei, S. (2014) Maximizing Wood Residue Utilization and Reducing Its Production Rate to Combat Climate Change. International Journal of Plant and Forestry Sciences, 1, $1-12$. 
[5] Clarke, J.M. (2018) Job Creation in Agriculture, Forestry and Fisheries in South Africa: An Analysis of Employment Trends, Opportunities and Constraints in Forestry and Wood Products Industries. Working Paper 52, Institute for Poverty, Land and Agrarian Studies (PLAAS), University of the Western Cape, Bellville.

[6] Okedere, O.B., Fakinle, B.S., Sonibare, J.A., Elehinafe, F.B. and Adesina, O.A. (2017) Particulate Matter Pollution from Open Burning of Sawdust in Southwestern Nigeria. Cogent Environmental Science, 3, Article ID: 1367112. https://doi.org/10.1080/23311843.2017.1367112

[7] Schmidt, G.B.S. (2014) Chinese Woods: A Case Study in the West-Zambian Timber Sector. 8th International Quality Conference, Kragujevac, 23 May 2014, 37-49.

[8] Claudiu, A. (2014) Use of Sawdust in the Composition of Plaster Mortars. ProEnvironment Promediu, 7, 30-34.

[9] Mamza, P.A., Ezeh, E.C., Gimba, E. and Arthur, D.E. (2014) Comparative Study of Phenol Formaldehyde and Urea Formaldehyde Particleboards from Wood Waste for Sustainable Environment. International Journal of Scientific \& Technology Research, 3, 53-61.

[10] Hurmekoski, E. (2017) How Can Wood Construction Reduce Environmental Degradation? European Forest Institute, Joensuu.

[11] Oliver, C.D., Nassar, N.T., Lippke, B.R. and Mccarter, J.B. (2014) Carbon, Fossil Fuel, and Biodiversity Mitigation with Wood and Forests. Journal of Sustainable Forestry, 33, 248-275. https://doi.org/10.1080/10549811.2013.839386

[12] Ekhuemelo, D. and Atondo, T. (2015) Evaluation of Lumber Recovery and Waste Generation in Selected Sawmills in Three Local Government Areas of Benue State, Nigeria. Applied Tropical Agriculture, 20, 62-68.

[13] Kambugu, R.K., Banana, A.Y., Zziwa, A., Agea, J.G. and Kaboggoza, J.R. (2005) Relative Efficiency of Sawmill Types Operating in Uganda's Softwood Plantations. Uganda Journal of Agricultural Sciences, 11, 14-19.

[14] Akhator, P., Obanor, A. and Ugege, A. (2017) Nigerian Wood Waste: A Potential Resource for Economic Development. Journal of Applied Sciences and Environmental Management, 21, 246-251. https://doi.org/10.4314/jasem.v21i2.4

[15] Olufemi, B., Akindeni, J.O. and Olaniran, S.O. (2012) Lumber Recovery Efficiency among Selected Sawmills in Akure, Nigeria. Drvna Industrija, 63, 15-18. https://doi.org/10.5552/drind.2012.1111

[16] Ncube, E. and Phiri, B. (2015) Concentrations of Heavy Metals in Eucalyptus and Pinus Wood Sawdust and Smoke, Copperbelt Province, Zambia. Maderas. Ciencia $y$ Tecnología, 17, 585-596. https://doi.org/10.4067/S0718-221X2015005000052

[17] Department of Environmental Affairs (DEA), South Africa State of Waste Report (2018) A Report on the State of the Environment, in Second Draft Report. DEA, Pretoria, 1-105.

[18] Guzman, A.D.M. and Munno, M.G.T. (2015) Design of a Brick with Sound Absorption Properties Based on Plastic Waste \& Sawdust. IEEE Access, 3, 1260-1271. https://doi.org/10.1109/ACCESS.2015.2461536

[19] Garay, R.M. (2012) Lab Testing for P3 Moisture Resistant Overlaid Particleboards Made from Wood Residues. BioResources, 7, 3093-3103.

[20] European Organisation of the Sawmill Industry (EOS) (2018) Annual Report of the European Sawmill Industry 2017/2018. EOS, Brussels. 
[21] Rominiyi, O., Adaramola, B., Ikumapayi, O., Oginni, O. and Akinola, S. (2017) Potential Utilization of Sawdust in Energy, Manufacturing and Agricultural Industry; Waste to Wealth. World Journal of Engineering and Technology, 5, 526-539. https://doi.org/10.4236/wjet.2017.53045

[22] Petrie, B. (2014) South Africa: A Case for Biomass? International Institute for Environment and Development, London.

[23] Deac, T., Fechete-Tutunaru, L. and Gaspar, F. (2016) Environmental Impact of Sawdust Briquettes Use-Experimental Approach. Energy Procedia, 85, 178-183. https://doi.org/10.1016/j.egypro.2015.12.324

[24] Meyer, C. (2002) Concrete and Sustainable Development. ACI Special Publications, 206, 501-512.

[25] Food and Agriculture Organisation (FAO) (2019) Forest Products Statistics. http://www.fao.org/forestry/statistics/80938/en

[26] Food and Agriculture Organisation (FAO) (2017) Global Forest Products: Facts and Figures 2016. Food and Agriculture Organisation of the United Nations, Roma.

[27] Ng'andwe, P., Chungu, D., Ratnasingam, J., Ramananantoandro, T., Donfack, P. and Mwitwa, J. (2017) Forestry Industry Development in Zambia: An Opportunity for Public Private Partnership for Small and Medium Enterprises. International Forestry Review, 19, 467-477. https://doi.org/10.1505/1465548822272374

[28] Abdulkareem, S., Raji, S. and Adeniyi, A. (2017) Development of Particleboard from Waste Styrofoam and Sawdust. Nigerian Journal of Technological Development, 14, 18-22. https://doi.org/10.4314/njtd.v14i1.3

[29] Dotun, A.O., Adediran, A.A. and Oluwatimilehin, A.C. (2018) Physical and Mechanical Properties Evaluation of Particle Board Produced from Saw Dust and Plastic Waste. International Journal of Engineering Research in Africa, 40, 1-8. https://doi.org/10.4028/www.scientific.net/JERA.40.1

[30] Akinyemi, A.B., Afolayan, J. and Oluwatobi, E.O. (2016) Some Properties of Composite Corn Cob and Sawdust Particle Boards. Construction and Building Materials, 127, 436-441. https://doi.org/10.1016/j.conbuildmat.2016.10.040

[31] Erakhrumen, A., Areghan, S., Ogunleye, M., Larinde, S. and Odeyale, O. (2008) Selected Physico-Mechanical Properties of Cement-Bonded Particleboard Made from Pine (Pinus caribaea M.) Sawdust-Coir (Cocos nucifera L.) Mixture. Scientific Research and Essay, 3, 197-203.

[32] Agoua, E., Allognon-Houessou, E., Adjovi, E. and Togbedji, B. (2013) Thermal Conductivity of Composites Made of Wastes of Wood and Expanded Polystyrene. Construction and Building Materials, 41, 557-562. https://doi.org/10.1016/j.conbuildmat.2012.12.016

[33] Chanhoun, M., Padonou, S., Adjovi, E.C., Olodo, E. and Doko, V. (2018) Study of the Implementation of Waste Wood, Plastics and Polystyrenes for Various Applications in the Building Industry. Construction and Building Materials, 167, 936-941. https://doi.org/10.1016/j.conbuildmat.2018.02.080

[34] Dawood, M.H.A., Abtan, Y.G. and Waryosh, W.A. (2013) Structural Behavior of Composite Sandwich Slab Panels. Journal of Engineering and Sustainable Development, 17, 220-232.

[35] Chung, H., Emms, G. and Fox, C. (2014) Vibration Reduction in Lightweight Floor/Ceiling Systems with a Sand-Sawdust Damping Layer. Acta Acustica United with Acustica, 100, 628-639. https://doi.org/10.3813/AAA.918742

[36] Antwi-Boasiako, C., Ofosuhene, L. and Boadu, K.B. (2018) Suitability of Sawdust 
from Three Tropical Timbers for Wood-Cement Composites. Journal of Sustainable Forestry, 37, 414-428. https://doi.org/10.1080/10549811.2018.1427112

[37] Mangi, S.A., Jamaluddin, N.B., Siddiqui, Z., Memon, S.A. and Ibrahim, M.H.B.W. (2019) Utilization of Sawdust in Concrete Masonry Blocks: A Review. Mehran University Research Journal of Engineering \& Technology, 38, 487.

[38] Gil, H., Ortega, A. and Pérez, J. (2017) Mechanical Behavior of Mortar Reinforced with Sawdust Waste. Procedia Engineering, 200, 325-332. https://doi.org/10.1016/j.proeng.2017.07.046

[39] Akers, D.J., Gruber, R.D., Ramme, B.W., Boyle, M.J., Grygar, J.G., Rowe, S.K., Bremner, T.W., Kluckowski, E.S., Sheetz, S.R. and Burg, R.G. (2003) Guide for Structural Lightweight-Aggregate Concrete, in ACI 213R-03. American Concrete Institute (ACI), Michigan.

[40] Mohammed, J.H. and Hamad, A.J. (2014) Materials, Properties and Application Review of Lightweight Concrete. Technical Review of the Faculty of Engineering University of Zulia, 37, 10-15.

[41] Ahmed, W., Khushnood, R.A., Memon, S.A., Ahmad, S., Baloch, W.L. and Usman, M. (2018) Effective Use of Sawdust for the Production of Eco-Friendly and Thermal-Energy Efficient Normal Weight and Lightweight Concretes with Tailored Fracture Properties. Journal of Cleaner Production, 184, 1016-1027. https://doi.org/10.1016/j.jclepro.2018.03.009

[42] Badejo, S.O.O. (1987) An Investigation on the Influence of Cement Binder Content on Properties of Cement-Bonded Particle Board from Four Tropical Hardwoods. Malaysian Forester (Malaysia).

[43] Olufemi, B. and Malami, A. (2011) Density and Bending Strength Characteristics of North Western Nigerian Grown Eucalyptus camaldulensis in Relation to Utilization as Timber. Research Journal of Forestry, 5, 107-114. https://doi.org/10.3923/rjf.2011.107.114

[44] Reyes, G., Brown, S., Chapman, J. and Lugo, A.E. (1992) Wood Densities of Tropical Tree Species. General Technical Report SO-88. US Dept of Agriculture, Forest Service, Southern Forest Experiment Station, New Orleans, 1-15.

[45] ANSI (American National Standards Institute) (2009) American National Standard for Particleboard. ANSI/A208.1. Composite Panel Association, Gaithersburg.

[46] BS EN 312 (2010) Particleboards. Specifications. European Committee for Standardization, Brussels.

[47] BS EN 317 (1993) Particleboards and Fibreboards. Determination of Swelling in Thickness after Immersion in Water. British Standards Institution, London.

[48] Atuanya, C.U. and Obele, C.M. (2016) Optimization of Process Parameter for Sawdust/Recycled Polyethylene Composites. Journal of Minerals and Materials Characterization and Engineering, 4, 270. https://doi.org/10.4236/jmmce.2016.44024

[49] Abu-Zarifa, A., Abu-Shammala, M. and Al-Sheikh, A. (2018) Sustainable Manufacturing of Particleboards from Sawdust and Agricultural Waste Mixed with Recycled Plastics. American Journal of Environmental Engineering, 8, 174-180.

[50] Kupolati, W.K., Grassi, S. and Frattari, A. (2012) Environmental Greening through Utilization of Sawdust for Production of Bricks. OIDA International Journal of Sustainable Development, 4, 63-78.

[51] SANS 10400 (2011) The Application of the National Building Regulations. Part K: Walls. SABS Standards Division, Pretoria.

[52] Ravindrarajah, R.S., Carroll, C. and Appleyard, N. (2001) Development of Sawdust 
Concrete for Block Making. Proceedings of the Construction Technology Conference, Kota Kinabalu, 12-14 October 2001.

[53] Dadzie, D.K., Dokyi, G.O. and Niakoh, N. (2018) Comparative Study of the Properties of Sandcrete Blocks Produced with Sawdust as Partial Replacement of Sand. International Journal of Scientific \& Engineering Research, 9, 1357-1362.

[54] Boob, T.N. (2014) Performance of Sawdust in Low-Cost Sandcrete Blocks. American Journal of Engineering Research, 3, 197-206.

[55] BS 6073 (1981) Part 1: Precast Concrete Masonry Units, Part 1. Specification for Precast Concrete Masonry Units. British Standards Institution, London.

[56] Ettu, L.O., Arimanwa, J.I., Njoku, F.C., Amanze, A.P.C. and Eziefula, U.G. (2013) Strength of Blended Cement Sandcrete \& Soilcrete Blocks Containing Sawdust Ash and Pawpaw Leaf Ash. International Journal of Engineering Inventions, 2, 35-40.

[57] Turgut, P. and Algin, H.M. (2007) Limestone Dust and Wood Sawdust as Brick Material. Building and Environment, 42, 3399-3403. https://doi.org/10.1016/j.buildenv.2006.08.012

[58] Moreira, A.B.S., Macêdo, A.N. and Souza, P.S.L. (2012) Masonry Concrete Block Strength Compound with Sawdust According to Residue Treatment. Acta Scientiarum. Technology, 34, 269-276. https://doi.org/10.4025/actascitechnol.v34i3.14372

[59] Adebakin, I.H., Adeyemi, A.A., Adu, J.T., Ajayi, F.A., Lawal, A.A. and Ogunrinola, O.B. (2012) Uses of Sawdust as Admixture in Production of Low-Cost and Lightweight Hollow Sandcrete Blocks. American Journal of Scientific and Industrial Research, 3, 458-463. https://doi.org/10.5251/ajsir.2012.3.6.458.463

[60] Zziwa, A., Kizito, S., Banana, A., Kaboggoza, J., Kambugu, R. and Sseremba, O. (2006) Production of Composite Bricks from Sawdust Using Portland Cement as a Binder. Uganda Journal of Agricultural Sciences, 12, 38-44.

[61] Osei, D.Y. and Jackson, E.N. (2016) Compressive Strength of Concrete Using Sawdust as Aggregate. International Journal of Scientific \& Engineering Research, 7, 1349-1353.

[62] Bdeir, L.M.H. (2012) Study Some Mechanical Properties of Mortar with Sawdust as a Partially Replacement of Sand. Anbar Journal for Engineering Sciences, 5, 22-30.

[63] Suliman, N.H., Razak, A.A.A., Mansor, H., Alisibramulisi, A. and Amin, N.M. (2019) Concrete Using Sawdust as Partial Replacement of Sand: Is It Strong and Does Not Endanger Health? MATEC Web of Conferences, 258, Article ID: 01015.

[64] Oyedepo, O.J., Oluwajana, S.D. and Akande, S.P. (2014) Investigation of Properties of Concrete Using Sawdust as Partial Replacement of Sand. Civil and Environmental Research, 6, 35-42.

[65] Nathan, M.V. (2018) Effect of Sawdust as Fine Aggregate in Concrete Mixture. International Journal of Engineering and Techniques, 4, 1-12.

[66] Chitra, R. and Hemapriya (2018) Experimental Study on Strength of Concrete by Partial Replacement of Fine Aggregate with Saw Dust. International Journal of Pure and Applied Mathematics, 119, 9473-9479.

[67] Sawant, A., Sharma, A., Rahate, R., Mayekar, N. and Ghadge, M.D. (2018) Partial Replacement of Sand with Sawdust in Concrete. International Research Journal of Engineering and Technology, 5, 3098-3101.

[68] Awal, A.A., Mariyana, A. and Hossain, M. (2016) Some Aspects of Physical and Mechanical Properties of Sawdust Concrete. International Journal of GEOMATE, 10, 1918-1923. 
[69] Sojobi, A.O. (2016) Evaluation of the Performance of Eco-Friendly Lightweight Interlocking Concrete Paving Units Incorporating Sawdust Wastes and Laterite. Cogent Engineering, 3, Article ID: 1133480. https://doi.org/10.1080/23311916.2016.1255168

[70] Sojobi, A.O., Aladegboye, O.J. and Awolusi, T.F. (2018) Green Interlocking Paving Units. Construction and Building Materials, 173, 600-614. https://doi.org/10.1016/j.conbuildmat.2018.04.061

[71] Olutoge, F.A. (2010) Investigations on Sawdust and Palm Kernel Shells as Aggregate Replacement. ARPN Journal of Engineering and Applied Sciences, 5, 7-13.

[72] Neville, A.M. (2011) Properties of Concrete. 5th Edition, Pearson Education Limited, Essex.

[73] ASTM C330/C330M-09 (2009) Standard Specification for Lightweight Aggregates for Structural Concrete. ASTM International, West Conshohocken.

[74] Sasah, J. and Kankam, C. (2017) A Study of Brick Mortar Using Sawdust as Partial Replacement for Sand. Lambert Academic Publishing, Mauritius, 1-66.

[75] Ogundipe, O. and Jimoh, Y. (2009) Durability-Based Appropriateness of Sawdust Concrete for Rigid Pavement. Advanced Materials Research, 62-64, 11-16. https://doi.org/10.4028/www.scientific.net/AMR.62-64.11

[76] Huseien, G.F., Memon, R.P., Kubba, Z., Sam, A.R.M., Asaad, M.A., Mirza, J. and Memon, U. (2019) Mechanical, Thermal and Durable Performance of Wastes Sawdust as Coarse Aggregate Replacement in Conventional Concrete. Jurnal Teknologi, 81, 151-161. https://doi.org/10.11113/jt.v81.12774

[77] Okoroafor, S.U., Ibearugbulam, O.M., Onukwugha, E.R., Anyaogu, L. and Adah, E.I. (2017) Structural Characteristics of Sawdust-Sand-Cement Composite. International Journal of Advancements in Research \& Technology, 6, 173-180.

[78] Udoeyo, F.F. and Dashibil, P.U. (2002) Sawdust Ash as Concrete Material. Journal of Materials in Civil Engineering, 14, 173-176. https://doi.org/10.1061/(ASCE)0899-1561(2002)14:2(173)

[79] Marthong, C. (2012) Sawdust Ash (SDA) as Partial Replacement of Cement. International Journal of Engineering Research and Applications, 2, 1980-1985.

[80] Obilade, I. (2014) Use of Saw Dust Ash as Partial Replacement for Cement in Concrete. International Journal of Engineering and Science Invention, 2319, 36-40.

[81] Dhull, H. (2017) Effect on Properties of Concrete by Using Saw Dust Ash as Partial Replacement of Cement. International Journal of Innovative Research in Science, Engineering and Technology, 6, 18603-18610.

[82] Onwuka, D., Anyaogu, L., Chijioke, C. and Okoye, P. (2013) Prediction and Optimization of Compressive Strength of Sawdust Ash-Cement Concrete Using Scheffe's Simplex Design. International Journal of Scientific and Research Publications, 3, $1-9$.

[83] Fapohunda, C., Akinbile, B. and Oyelade, A. (2018) A Review of the Properties, Structural Characteristics and Application Potentials of Concrete Containing Wood Waste as Partial Replacement of One of Its Constituent Material. YBL Journal of Built Environment, 6, 63-85. https://doi.org/10.2478/jbe-2018-0005

[84] Mangi, S.A., Jamaluddin, N., Wan Ibrahim, M., Noridah, M. and Sohu, S. (2017) Utilization of Sawdust Ash as Cement Replacement for the Concrete Production: A Review. Engineering Science and Technology International Research Journal, 1, 11-15.

[85] Raheem, A., Olasunkanmi, B. and Folorunso, C. (2012) Saw Dust Ash as Partial Re- 
placement for Cement in Concrete. Organization, Technology \& Management in Construction: An International Journal, 4, 474-480. https://doi.org/10.5592/otmcj.2012.2.3

[86] Asdrubali, F., D’Alessandro, F. and Schiavoni, S. (2015) A Review of Unconventional Sustainable Building Insulation Materials. Sustainable Materials and Technologies, 4, 1-17. https://doi.org/10.1016/j.susmat.2015.05.002

[87] Memon, R.P., Sam, A.R.M., Awal, A.A. and Achekzai, L. (2017) Mechancal and Thermal Properties of Sawdust Concrete. Jurnal Teknologi (Sciences \& Engineering), 79, 23-27. https://doi.org/10.11113/jt.v79.9341

[88] Salih, S.A. and Kzar, A.M. (2015) Studying the Utility of Using Reed and Sawdust as Waste Materials to Produce Cementitious Building Units. Journal of Engineering, 21, 36-54.

[89] Sindanne, S.A., Ntamack, G.E., Sanga, R.P.L., Moubeke, C.A., Sallaboui, E.S.K., Bouabid, H., Mansouri, K. and D’ouazzane, S.C. (2014) Thermophysical Characterization of Earth Blocks Stabilized by Cement, Sawdust and Lime. Journal of Building Materials and Structures, 1, 58-64.

[90] AbdulAmeer, O. (2018) Assessment the Thermal Properties Lightweight Concrete Produced by Using Local Industrial Waste Materials. MATEC Web of Conferences, 162, Article ID: 02027. https://doi.org/10.1051/matecconf/201816202027

[91] Cheng, Y., You, W., Zhang, C., Li, H. and Hu, J. (2013) The Implementation of Waste Sawdust in Concrete. Engineering, 5, 943.

https://doi.org/10.4236/eng.2013.512115

[92] Asadi, I., Shafigh, P., Hassan, Z.F.B.A. and Mahyuddin, N.B. (2018) Thermal Conductivity of Concrete-A Review. Journal of Building Engineering, 20, 81-93. https://doi.org/10.1016/j.jobe.2018.07.002

[93] Tarmac, L. (2015) Low Thermal Conductivity Concrete, in Solution Guide. Lafarge Tarmac Limited, Solihull.

[94] Baden-Powell, C. (2008) Architect's Pocket Book. 3rd Edition, Architectural Press, Elsevier, Oxford. https://doi.org/10.4324/9780080490458

[95] ASTM C332-09 (2009) Standard Specification for Lightweight Aggregates for Insulating Concrete. ASTM International, West Conshohocken.

[96] Qui, H. and Enhui, Y. (2018) Effect of Thickness, Density and Cavity Depth on the Sound Absorption Properties of Wool Boards. Autex Research Journal, 18, 203-208. https://doi.org/10.1515/aut-2017-0020

[97] Leventhall, H. (2004) Low Frequency Noise and Annoyance. Noise and Health, 6, 59.

[98] Seddeq, H.S. (2009) Factors Influencing Acoustic Performance of Sound Absorptive Materials. Australian Journal of Basic and Applied Sciences, 3, 4610-4617.

[99] Tiuc, A.-E., Vermeşan, H., Gabor, T. and Vasile, O. (2016) Improved Sound Absorption Properties of Polyurethane Foam Mixed with Textile Waste. Energy Procedia, 85, 559-565. https://doi.org/10.1016/j.egypro.2015.12.245

[100] Tiuc, A.E., Vasile, O. and Gabor, T. (2014) Determination of Antivibrational and Acoustical Properties of Some Materials Made from Recycled Rubber Particles and Sawdust. Romanian Journal of Acoustics and Vibration, 11, 47-52.

[101] Kang, C.-W., Oh, S.-W., Lee, T.-B., Kang, W. and Matsumura, J. (2012) Sound Absorption Capability and Mechanical Properties of a Composite Rice Hull and Saw- 
dust Board. Journal of Wood Science, 58, 273-278.

https://doi.org/10.1007/s10086-011-1243-5

[102] Tiuc, A.E., Nemeş, O., Vermeşan, H. and Toma, A.C. (2019) New Sound Absorbent Composite Materials Based on Sawdust and Polyurethane Foam. Composites Part B: Engineering, 165, 120-130. https://doi.org/10.1016/j.compositesb.2018.11.103

[103] Dance, S. and Shield, B. (2000) Absorption Coefficients of Common Construction Materials for Use in Computer Modelling of Enclosed Spaces. Building Acoustics, 7, 217-224. https://doi.org/10.1260/1351010001501615

[104] Vorländer, M. (2007) Auralization: Fundamentals of Acoustics, Modelling, Simulation, Algorithms and Acoustic Virtual Reality. Springer Science \& Business Media, Berlin.

[105] Tiuc, A.-E., Dan, V., Vermeşan, H., Gabor, T. and Proorocu, M. (2016) Recovery of Sawdust and Recycled Rubber Granules as Sound Absorbing Materials. Environmental Engineering \& Management Journal, 15, 1093-1101. https://doi.org/10.30638/eemj.2016.122

[106] Chudley, R. and Greeno, R. (2013) Building Construction Handbook. 9th Edition, Routledge, Abingdon-on-Thames. https://doi.org/10.4324/9780080970622

[107] Chung, H., Fox, C., Dodd, G. and Emms, G. (2010) Lightweight Floor/Ceiling Systems with Improved Impact Sound Insulation. Building Acoustics, 17, 129-141. https://doi.org/10.1260/1351-010X.17.2.129

[108] Emms, G., Chung, H., Mcgunnigle, K. and Dodd, G. (2006) Improving the Impact Insulation of Light Timber Floors. in Proceedings of Acoustics 2006, Christchurch, 20-22 November 2006, 147-153.

[109] Chathurangani, O., Perera, W., Kumari, H., Subashi, G. and De Silva, G. (2013) Utilization of Sawdust and Coconut Coir Fibre as Noise Reducing Wall Surface Materials. Civil Engineering Research Exchange Symposium, Matara, 16-19.

[110] Setyowati, E., Hardiman, G. and Atmaja, S.T. (2015) Green Materials Comparison of Sawdust and Coconut Fiber Acoustical Waffle Panel. Applied Mechanics and Materials, 747, 221-225. https://doi.org/10.4028/www.scientific.net/AMM.747.221 